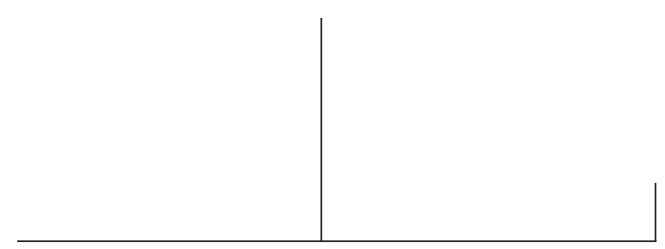

Rev. Latinoam. Psicop. Fund., II, 3, 9-45

\title{
Nascimento de um corpo, origem de uma história*
}

\author{
Piera Aulagnier
}

Partindo do pressuposto de que toda história significante se constrói a partir do nascimento de um corpo - corpo este que deverá ser investido libidinalmente - a autora discute os movimentos constitutivos da psique e sua relação com o corpo. A ênfase é dada ao postulado do auto-engendramento que diz que enquanto o espaço psíquico e o espaço somático estão indissociáveis, a psique imputará à atividade das zonas sensoriais o poder de engendrar suas experiências.

A autora parte daquilo que o corpo torna visivel nos registros da emoção e do sofrimento somático, para compreender seu papel na construção do "corpo latente", que é o seu duplo psíquico.

A “aquisição" do corpo pelo Eu (Je) é seguida passo a passo no texto. A "historização" da vida somática só pode ser feita por um biógrafo: o Eu. Este Eu (Je) deve, entretanto, ser capaz de reconhecer como seus os eventos que marcaram significativamente sua vida. Para que o biógrafo e biografia existam é necessário que psique e corpo passem a se relacionar como pólos separados,

* Tradução de Vera Conrad 


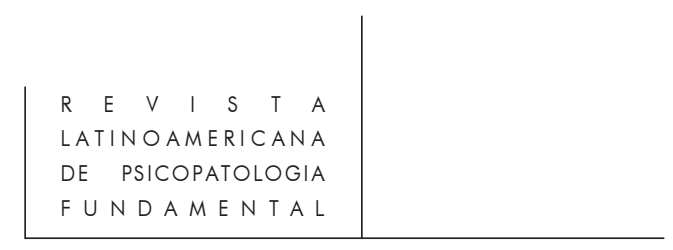

marcando assim a passagem do corpo sensorial ao corpo relacional. $O \mathrm{Eu}(\mathrm{Je})$ só pode ocupar um corpo que possua uma história. A primeira versão desta história é elaborada pela psique que acolhe este corpo. Nesta história estará contido um "Eu (Je) antecipado", referente à imagem do corpo da criança que a mãe antecipa, permitindo assim que a criança seja inserida num sistema de parentesco. Contudo, a situação pode complicar-se quando a imagem criada pela mãe não corresponde ao corpo com o qual a criança vem ao mundo. Os conflitos insuportáveis e os lutos irrealizáveis gerados por essa situação são ampla e longamente debatidos: a psicose, o autismo, as manifestações psicossomáticas, as somatizações polimorfas.

No final do texto são analisadas, de forma pormenorizada, as conseqüências da não ancoragem do representante psíquico que a mãe traz do corpo do infans na realidade do corpo com o qual a criança nasce.

Palavras-chave: Psicanálise, corpo, história, investimento 


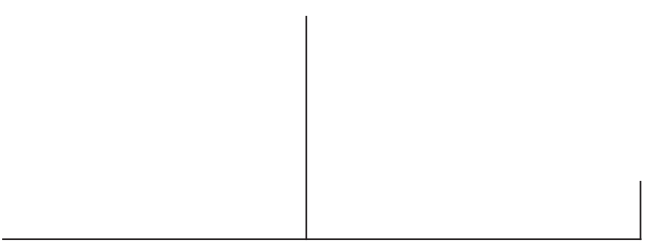

\section{Preâmbulo}

$\mathrm{O}$ viajante que percorre o mundo mítico terá certeza de encontrar aí adivinhos e, no meio deles, alguns cegos ilustres. Estes últimos o ensinarão qual o castigo que espera aquele que, ao realizar um desejo proibido, ousou tornar conhecível, manifesto, a si próprio e aos outros, o que deveria ter permanecido ignorado, latente. Mas o poder divinatório destes poderia sugerir ao mesmo viajante que o verdadeiro conhecimento exige que nós liberemos desta tela que constitui o visível. Ou dá-se crédito ao mundo sensível, acreditando que a realidade está conforme com a sua aparência ou não se deixa cair na armadilha e o melhor, neste caso, é eliminar a armadilha.

Porém, se seguíssemos ao pé da letra este conselho, daríamo-nos conta muito rapidamente de que a realidade humana e não mais mítica só se deixa captar através desta atividade sensorial que serve de deletor e de ponte de passagem entre a realidade psíquica e estes espaços nos quais ela colhe seus materiais, a começar por seu próprio espaço somático.

Antes de abordar a função que vai desempenhar o corpo como mediador e aposta relacional (enjeu) entre duas psiques e entre a psique e o mundo, consideramos as três formas de existência sob as quais a realidade (e logo o corpo) se apresenta ao ser humano, sendo a quarta dada pelo compromisso que deverá resultar daí. Uso aqui o termo realidade na sua acepção menos teórica e a mais natural para o pensamento humano: para o sujeito a realidade coincide com a totalidade dos fenômenos cuja existência é uma evidência. Isso não quer dizer 


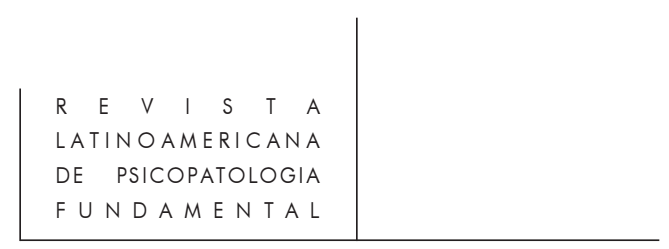

que todo sujeito reconheça um mesmo conjunto de existentes, mas que para todos, ao contrário, só este conjunto terá lugar nas construções de sua realidade.

Mas estas construções, sejam elas obra do processo originário, primário ou secundário nos ensinam também de que maneira reage a psique na presença de todo fenômeno que tem o poder de modificar seu estado afetivo.

É este poder que, ao transformá-lo num evento psíquico, impõe à psique a evidência de sua presença. Todo ato de conhecimento é precedido de um ato de investimento e, este último, é desencadeado pela experiência afetiva que acompanha este estado de encontro, sempre presente, entre a psique e este meio - físico, psíquico, somático - que o cerca.

A realidade psíquica tal como Freud a define, testemunha dos efeitos sucessivos e instáveis (mouvants) do seu encontro com este meio cujas modificações "apontarão" à psique suas reações ao encontro. A psique decodificará estes sinais utilizando chaves diferentes conforme o momento em que se opera esta inter-reação. Veremos no fim deste preâmbulo como o processo originário trata estes primeiros sinais relacionais ou estes "julgamentos de existência" dos quais ele vai sofrer os efeitos, ainda que ignore a exterioridade de sua fonte, para considerar em primeiro lugar o que se coloca a partir do momento em que a psique pode reconhecer a existência de um outro e de um mundo separados dela mesma. Os fenômenos que a obrigam a levar em conta o conceito de separável (não fundamental, segundo a expressão de Freud, para o funcionamento psíquico), poderão ser as manifestações do desejo agindo na psique destes outros ocupantes do mundo ou, ainda, a consequiência das leis que organizam o espaço sócio-cultural, ou ainda daquelas que regem o funcionamento somático. Manifestações heterogêneas, mas que a psique não só vai incluir no mesmo termo de realidade, mas entre as quais ela vai começar a colocar uma mesma relação de causa e efeito. Na organização deste fragmento de realidade que ele habita e investe como no funcionamento do seu corpo, o sujeito vai ler primeiro as consequiências do poder exercido pela psique destes outros que o cercam e que são os suportes privilegiados dos seus investimentos.

Donde esta primeira formulação que a criança vai se dar da realidade: $a$ realidade é regida pelo desejo dos outros.

Na primeira infância, o sujeito guarda a convicção de que tudo que acontece ou que não acontece no meio ambiente, tudo que toca seu corpo, tudo que modifica seu vivido psíquico vem testemunhar do poder que ele imputa ao desejo (o seu e o dos pais), que estes eventos, por diferentes que sejam, são os sinais através dos quais um desejo confesso ou oculto, permitido ou proibido, toma uma forma visível para seu olhar. (Concepção infantil sempre ativa no adulto, seja qual for a instância que ele substituirá aos pais: cada vez que um acontecimento do mundo incidir sobre nossa existência e desarranjá-la, o acaso raramente terá lugar no registro das causas. 


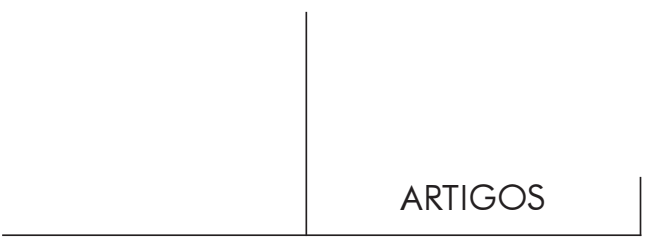

Se o sujeito está disposto a reconhecer a "naturalidade" do acontecimento, nem por isso ele reconhecerá a "naturalidade" do seu encontro com este último.)

Mas uma vez passada a infância, o sujeito não poderá conviver com seus parceiros no mesmo espaço sócio-cultural, se ele não aderir ao consenso respeitado pela grande maioria dos seus ocupantes sobre aquilo que irão definir como realidade. Sem este consenso, nenhuma sociedade, seja ela qual for, poderia preservar-se; caso não possa partilhá-lo o sujeito se encontrará excluído dele.

Daí, a consideração pelo sujeito desta segunda formulação: a realidade está conforme ao conhecimento que dela dá o saber dominante de uma cultura.

Convém lembrar, se necessário, que este constar não data de hoje e nem da era freudiana: sabe-se há muito tempo que para o homem não há realidade natural nem sequer realidade puramente sensorial. O que aparece sobre a retina do olho que vê uma árvore é sem dúvida idêntico, mas o que o sujeito percebe será muito diferente, reconhecendo nesta árvore uma espécie vegetal ou o depositário do espírito de um ancestral. O analista é o mais bem colocado para saber que nós não poderemos nunca conhecer do interior o que vê este outro sujeito. ${ }^{1}$

Devemos a Freud esta última fórmula: a realidade, em última análise, é inconhecível. Fórmula que, desta vez, é o constar de um pensamento teórico que percorreu o que ele podia conhecer da realidade e que soube aceitar que um resto se furta indefinidamente a esta tomada de conhecimento.

Este "resto" que se situa fora do conhecível parece-me próximo daquilo que Lacan definiu de conceito de real diferenciado daquele de realidade. O real, eu diria parafraseando uma outra expressão de Lacan, é o que resiste à realidade na qualidade de realidade para e do humano. Mas é preciso ainda incluir neste humano o analista e reconhecer que, como todo sujeito, ele está sujeito aos limites que a "natureza" de sua psique impõe ao trabalho do seu pensamento, a seu objetivo de conhecimento.

Mas deixemos os teóricos para retornar ao profano: as duas formulações propostas acima supõem, como se viu, que a psique tenha podido operar este "passo fundamental" que permitiu-lhe reconhecer a existência de um outro lugar (alhures). Mas como era isso antes deste momento? Enquanto espaço psíquico e espaço somático permanecem indissociáveis, enquanto nenhum existente exterior pode ser conhecido como tal, tudo que afeta a psique, tudo que modifica seus próprios experimentados responderá ao único postulado do auto-engendramento. A psique imputará à atividade das zonas sensoriais o poder de engendrar seus próprios experimentos (prazer ou sofrimento), seus próprios movimentos de investimento

1. É claro, o impacto do discurso cultural é fundamental na organização do nosso mundo relacional e ético: da mesma forma, este mesmo discurso nos fornece os únicos critérios capazes de decidir o verdadeiro eo falso de nossos julgamentos. 
ou de desinvestimento e, em conseqüência, a única "evidência" que pode existir nesta alvorada da vida.

Neste tempo que precede a prova da separação, a realidade, termo que merece aqui duplas aspas, vai coincidir totalmente com seus efeitos sobre a organização somática, com as modificações, as reações que aí tomam lugar. A única formulação que se poderia aplicar seria a seguinte: a realidade é auto-engendrada pela atividade sensorial.

Uma vez reconhecida a exterioridade do seio, primeiro representante de um mundo separado, o sujeito terá acesso a este novo espaço de realidade no qual "sinais" captados pelos nossos sentidos informarão os dois suportes de toda relação do que eles percebem ou supõem dos seus desejos recíprocos: estes sinais fazem parte, por excelência, do fantasmável, do interpretável, do pensável. Por mais diferentes que sejam, eles vão com partilhar um mesmo caráter: sua presença ou sua ausência exerce um poder de modificação sobre o próprio meio ambiente, sobre o corpo e, antes de tudo, sobre o estado psíquico. Modificação objetiva ou modificação que somente o interpretante vê, ou acredita ver, o que será suficiente para que se opere uma automodificação do seu próprio vivido psíquico.

É por isto que se pode antecipar que nosso espaço relacional encontra seus pontos de ancoragem nos indícios que se apresentam e se inscrevem sobre a cena da realidade as modificações que ocorrem no espaço psíquico dos dois pólos da relação. Estas "modificações" vão assumir uma função sinalizadora particular quando se referem ao espaço analítico.

As três formulações que propus para justificar a relação da psique com a realidade podem aplicar-se tais quais à relação presente entre a psique e o próprio espaço somático. Ainda aqui a atividade das zonas sensoriais, o todo-poder do desejo, o que enuncia o discurso cultural sobre o corpo, darão lugar a três representações do corpo e a três formas de conhecimento que a psique se dá dele: tomadas de conhecimento que se sucedem no tempo, sem por isso excluir-se uma da outra. Elas nos confrontam com as três formas de existência e com os três princípios de causalidade que a realidade e o corpo devem preservar para não colocar em perigo seus investimentos, e é por isso que todas as três tomarão parte deste compromisso que constitui aí a quarta e a mais determinante para nosso funcionamento psíquico.

A relação de todo sujeito a este corpo que o confronta com a sua realidade mais próxima, mais familiar e mais investida, dependerá do compromisso que ele terá conseguido estabelecer entre três concepções causais do corpo, das quais as duas primeiras respondem a exigências psíquicas universais e atemporais, enquanto a última será não somente função do tempo e do espaço cultural próprios do sujeito, mas também a única que a psique pode rejeitar ou remodificar e reinterpretar, para torná-la com-possível com as duas outras. Nossa relação com o corpo, assim como nossa relação com a realidade é, portanto, função da maneira como o sujeito ouve, 


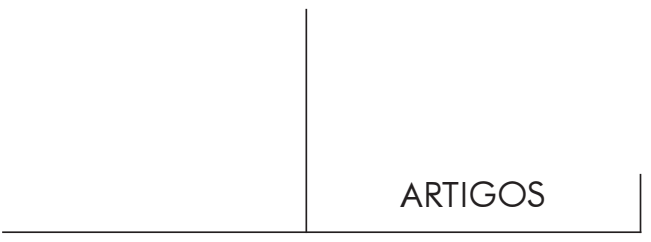

deforma ou permanece surdo ao discurso do conjunto. É evidente que suas reações são a conseqüência da especificidade da sua economia psíquica e não da particularidade da sua cultura, salvo sob certas condições excepcionais. Mas a análise dos postulados da mensagem cultural parece uma excelente via para abordar aquela das respostas que a psique vai lhe dar.

Não creio trair a complexidade do andamento analítico quando digo que seu propósito é conseguir tornar evidentes as razões e as desrazões responsáveis do compromisso escolhido por este sujeito particular e as conseqüências que resultam na sua relação com o corpo, com os outros e com ele próprio. Mas para isso estamos obrigados a nos referir a uma forma de compromisso que julgamos no essencial, partilhada pelo conjunto desses sujeitos que puderam permanecer fora do campo da psicopatologia: compromisso que eu não sei muito bem se convém defini-lo como majoritário ou normal, mas compromisso que permite ao analista constatar e avaliar o impacto do discurso dominante numa dada cultura, discurso científico na nossa.

Daí a pergunta que coloco: o que significou para nossa relação com o corpo, para uma apreensão de nosso próprio funcionamento somático, o declínio do discurso religioso em proveito do discurso científico? (A mesma pergunta poderia ser colocada para nossa relação com a realidade, com o social, com a lei... Mas acontece que é o corpo que ocupa um lugar pivô neste trabalho.) Não tenho - é claro - a ambição de responder a uma pergunta tão complexa e tão fundamental. Limitar-me-ei a apontar dois caráteres que separam e especificam o corpo tal como o discurso religioso nos fazia pensar e o corpo tal como nos dá a conhece-lo o discurso científico: o primeiro se refere ao lugar, dado pelo primeiro e negado pelo segundo, do desejo na origem e no destino do corpo; o segundo se refere ao registro do visível.

A concepção religiosa do mundo que, durante séculos, marcou a nossa cultura, certamente não é redutível a um fantasma. Toda religião é o resultado de um longo trabalho de elaboração, de sublimação, de recalcamento... Além disso, este corpo que os textos sagrados nos afirmavam ser conforme ao modelo de um primeiro corpo criado por Deus, este corpo que encontraremos intacto quando da Ressurreição, pôde conviver com uma representação fantasmática que religará sempre seu representado e, logo, o corpo a um desejo. Todo discurso cultural tem como missão operar uma espécie de aculturação de uma parte dos propósitos fantasmáticos: não é do poder deste discurso eliminá-los, mas é do seu poder oferecer-lhes objetivos substitutivos, compensações parciais. Esta missão terá tanto mais chances de ser bem-sucedida quando desejo continua a ter lugar no que a cultura enuncia sobre a organização, o destino, a natureza dos homens e das coisas. O que especifica o corpo ao qual nos confronta a ciência é a exclusão do desejo como causa do seu funcionamento e como explicação causal do seu destino e de sua morte. 


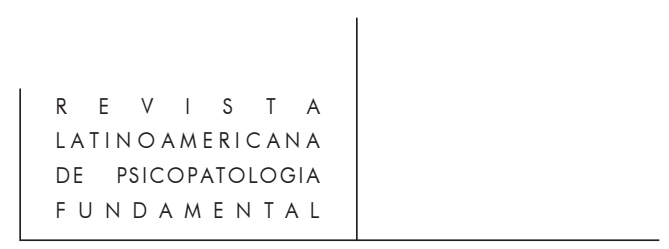

Este saber científico, este mesmo saber dentro do qual tomou lugar o discurso analítico que não teria sido nem pensável, nem recebível num outro tempo, pouco importa as contradições, as recusações recíprocas que opõem estes dois saberes, se deu como objetivo - seja qual for o campo de pesquisa que ele privilegia - a demonstração de uma verdade que não pode mais fazer parte do sagrado, pretendendo-se uma revelação imutável.

$\mathrm{O}$ que sucedeu a partir do momento que o corpo se tornou um objeto privilegiado de observação e de pesquisa? A qual desejo, a qual visão do corpo nos reenvia a ciência? Qual o corpo nos incitava a ver o discurso sagrado; que outra imagem nos impõem o discurso científico?

Antes que o olhar do homem de ciência voltasse para o corpo, o único objeto de observação era um corpo visível e um corpo unificado enquanto o seu interior permanecia invisível para ele, preservando-se assim o enigma de seu funcionamento. O "sabedor" e o profano só tratavam de corpos inteiros: o primeiro pôde sustentar suas certezas ao abrigo do demonstrável sobre a relação presente entre os sinais visíveis de um sofrimento e um interior invisível. Esta preservação de uma dimensão invisível permitia ao sujeito profano fazer coabitar sem dificuldade a causalidade "sabedora" imputada à sua doença e a causalidade divina imputada ao ser assim do seu corpo. Enquanto a Igreja pôde proibir a dissecação e enquanto esta proibição foi respeitada, o olhar estava protegido do encontro com um corpo que o teria confrontado a um interior feito de partes, de órgãos, de pedaços.

Esta fragmentação foi se acentuando mais e mais: a biologia não mais estuda os grandes sistemas; ela estuda a célula e, além disso, os elementos que a compõem. Este saber substituiu a imagem de um corpo, a imagem de uma junção de milhares de células a serviço de uma máquina altamente sofisticada e cujo funcionamento escapa ao conhecimento que dela poderia ter o profano: "E Deus criou a célula". Pouco importa que este enunciado seja verdadeiro ou falso, mas basta formulá-lo para perceber que não se pode mais acrescentar "à imagem (semelhança) das células de Deus".

Claro, o sujeito pode tornar a dar lugar a um Deus criador, atribuindo-lhe um projeto tocante ao vivente na sua totalidade: mas como Freud já fazia observar a respeito de Darwin, será que podemos ter a certeza de que o homem pode se satisfazer do lugar que um tal projeto lhe destina? Eu duvido disso. Seja como for, o que me interessa aqui não é a relação do homem com Deus, mas sua relação com seu corpo. Desde que ao corpo como totalidade substituiu-se a célula para tentar elucidar as leis do seu próprio funcionamento, e desde que se mostrou que estas leis tocam ao conjunto das células que constituem o vivente, torna-se bem difícil ao sujeito colocar um desejo como causa e organizador do seu funcionamento somático. Os destinos do seu corpo situam-se fora do desejo. Enquanto o conhecimento do corpo privilegiava seu visível, o sujeito podia construir-se à imagem 


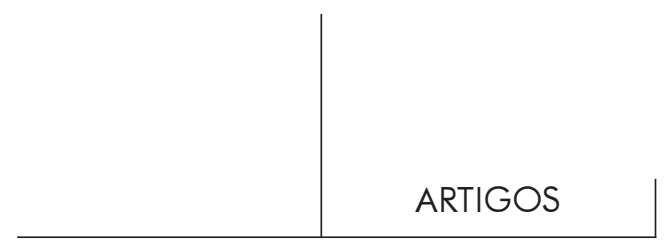

de um interior que lhe ficava familiar, que ele podia tornar-se dizível, recorrendo a metáforas compatíveis com suas construções fantasmáticas. No momento em que este interior ficou visível, ele se tornou, de repente, paradoxalmente, aquilo que o sujeito profano não pode mais conhecer a não ser confiando no único saber dos especialistas. Outros sabem, outros têm o poder de demonstrar a verdade de suas afirmações, outros têm o poder de agir sobre o funcionamento do corpo. Este saber sobre o corpo faz parte, bem entendido, de uma pesquisa que, além do corpo, interroga o conjunto dos fenômenos do mundo. E é por isso que discurso mítico, discurso religioso, discurso científico, levam, em última análise, ao mesmo resultado: impor sua construção da realidade. (Abrirei aqui um rápido parêntese para sublinhar que uma das conseqüências particulares do discurso científico foi desde sempre, mas de uma maneira cada vez mais radical, a colocação em dúvida desta certeza, desta evidência fundamental, das quais gozavam nossos testemunhos sensoriais. Mas não devemos nos esquecer que, para que o funcionamento psíquico de todo homem se preserve, é necessário que este questionamento se desloque a um nível teórico e não interfira no cotidiano da sua existência.)

Voltemos ao corpo da ciência e ao que pode ou não pode fazer o sujeito profano dos conhecimentos que dele terá. Rejeitá-los em conjunto implicaria, ao mesmo tempo, que ele rejeita o que a ciência - e logo nossa cultura - diz sobre a realidade: vimos que o sujeito não pode sustentar esta recusa, a não ser excluindo-se do seu espaço social e que, para conservar aí seu lugar, deve aceitar um consenso sobre aquilo que recobre o termo realidade e, para isso, operar um empréstimo "obrigatório" ao saber dominante da sua cultura.

Em nosso espaço-tempo a escola, as mass média, o discurso que circula, vão propor, impor a todo sujeito a apropriação de certos elementos de conhecimento mais ou menos fragmentários e mais ou menos confusos, mas graças aos quais vai dispor de um discurso teórico do corpo que se refere a um corpo-padrão e a um corpo universal, mas do qual faz parte também o seu próprio. Corpo-padrão ou padrão do funcionamento do corpo que, por mais diferente que seja daquilo que a ciência diz dele, é um derivado dele. Este derivado vai sofrer um duplo tratamento: por um lado, o sujeito extrairá deste discurso um certo número de enunciados, graças aos quais este saber teórico sobre o corpo - e logo sobre a realidade - poderá fazer parte do seu compromisso global. A escolha destes enunciados dependerá de sua aptidão em compor com um corpo fantasmável e investível pela psique.

Por outro lado, o sujeito vai se servir de outros enunciados para dar forma e lugar a uma construção teórica do corpo que ele vai preservar, com alguns outros de mesma espécie, numa "reserva" do seu capital ideativo. Reserva que faz pendente àquela cuja tarefa é proteger da luz do dia os fantasmas recalcados. Esta "reserva ideativa" (lembro a você que eu me situo e que permaneço no registro das 


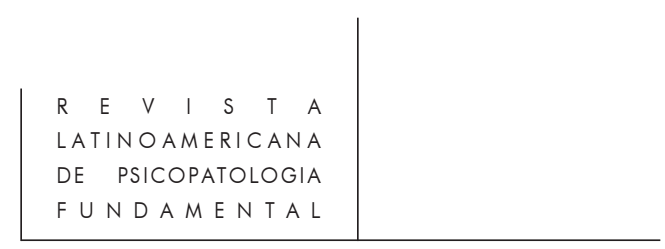

construções do Eu $(\mathrm{Je})^{*}$ está ao abrigo da ação do recalcamento: o sujeito conserva o poder de guardar a distância, numa espécie de esquecimento, as construções que ela contém ou, ao inverso, de memorizá-las para fazer delas, sob estas condições, o referente psíquico privilegiado do seu corpo. (Falo, claro, do sujeito profano e não do científico, cuja relação com suas próprias descobertas e conhecimentos mereceria uma análise particular que nos ensinaria, sem dúvida, muitas coisas sobre o que se pode ou não definir de clivagem.)

O lugar assim ocupado, em situações particulares, por estas construções "teóricas" vai atribuir-lhes uma tarefa toda específica: fazer um papel de párafantasma (para $=$ garantir de, proteger), em proveito do sujeito e do seu corpo. Este longo desvio sobre a realidade, o corpo, as exigências culturais, pareceu-me necessário antes de abordar o estatuto psíquico do corpo falado.

\section{Os discursos sobre o corpo}

Freud nos ensinou que não se pode analisar o conteúdo latente de um sonho a não ser partindo do seu conteúdo manifesto. Por isso, partirei daquilo que nosso corpo torna visível nos registros da emoção e do sofrimento somático ${ }^{2}$, para tentar compreender seu papel na construção deste "corpo latente" que é sua face e seu duplo psíquico.

As representações sucessivas deste corpo acompanharão a evolução da vida somática, mas este corpo será cada vez conforme com as motivações inconscientes que decidem sobre as causalidades às quais o sujeito imputa os acontecimentos marcantes do seu vivido. Esta escolha causal vai, por sua vez, decidir o lugar que vai ocupar o corpo (seu nascimento, seu desenvolvimento, sua morte futura) nesta historização de seu tempo e de sua vida, que é o pressuposto que inaugura e dá prosseguimento ao processo identificatório. $\mathrm{O} E u(\mathrm{Je})$ só pode ser quando ele se torna a ser seu próprio biógrafo e, na sua biografia, ele deverá dar lugar aos discursos através dos quais fala e através dos quais seu próprio corpo se torna falante. Estes discursos sobre seu corpo singular dão à palavra as únicas inscrições e modificações que o sujeito poderá ler e decodificar como as marcas visíveis de uma história libidinal que se inscreveu e continua a gravar-se sobre esta face invisível que é a psique: história libidinal, mas o mesmo tanto história identificatória. Uma vez esta história

* Optou-se por traduzir $J e$ por Eu $(\mathrm{J} e$ ) para lembrar da diferença - que não existe em português - entre $\mathrm{Eu}(\mathrm{Je})$ e $\mathrm{Eu}(m o i)$.

2. Muitos outros signos que fazem parte deste corpo visível, a começar por aqueles que dizem respeito à sexualidade, merecem igual atenção. Mas o que me interessa é o "tratamento" que a psique dá a certas manifestações somáticas, das quais ela se faz mensageiro. 


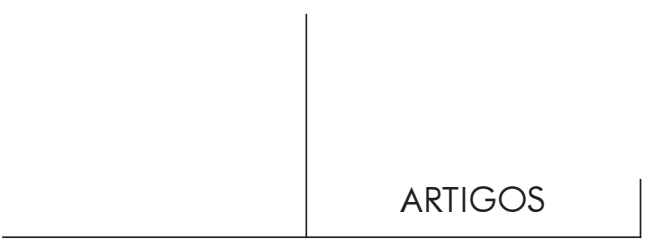

escrita, ela exigirá periodicamente a inversão de uma parte dos parágrafos, tornará necessário o desaparecimento de certos e a invenção de outros, para resultar numa versão que o sujeito crê a cada vez definitiva, enquanto ela deve permanecer aberta para prestar-se a um trabalho de reconstrução, de reorganização dos seus conteúdos e, antes de tudo, das suas causalidades cada vez que isto se revelar necessário. Só porque esta versão permanece movente, o sujeito pode certificar-se da sua própria permanência, aceitando ao mesmo tempo as inevitáveis mudanças físicas e psíquicas que se sucederão enquanto a morte não vem pôr aí um fím.

Esta permanência necessária de certas referências identificatórias desapareceria se o Eu ( $\mathrm{J}$ ) não guardasse a certeza de habitar um mesmo e único corpo, sejam quais forem suas modificações.

Por isso o Eu (Je) vai imputar uma mesma função relacional e uma mesma causalidade a um certo número de experimentos e de experiências, embora tenham vividos por seu corpo em tempos e situações diferentes. Esta analogia reconstruída num depois, próximo ou longínquo, do acidente-evento é necessária para colocar no lugar estes pontos de acolchoado religados entre eles por um fio vermelho, graças ao qual o Eu ( $\mathrm{Je}$ ) pode achar o caminho e se orientar nesta história (a sua) que, como toda história, se especifica pelo seu movimento contínuo.

Daí a importância que é preciso conceder a este conjunto de "sinais" e inscrições corporais que podem prestar-se a esta função de referências temporais e relacionais.

Têm lugar neste conjunto as manifestações somáticas da emoção e aquelas que vêm anunciar ao sujeito e aos outros um estado de sofrimento no seu próprio corpo: estas são as únicas sobre as quais eu me apoiarei neste trabalho.

O termo emoção, ao contrário de afeto, não goza de um lugar particular na terminologia analítica. Sinto-me, desta feita, mais à vontade para dar-lhe uma acepção bem precisa e designar com ele a parte imersa deste iceberg que é o afeto e logo as manifestações subjetivas destes movimentos de investimento e de desinvestimento, que o Eu (Je) só não pode entender porque eles se tornam para ele fonte de emoção. $\mathrm{O} \mathrm{Eu}(\mathrm{Je})$ pode ignorar na sua relação com outro e o mundo o papel que representam estes afetos que são a inveja, o ódio, o amor; ele geralmente não reconhece que eles são responsáveis por sua maneira de viver esta relação e permanece convencido de que é preciso procurar a causa disso no exterior. Ao contrário, a emoção se refere a um vívido do qual o Eu (Je) não só tem conhecimento, mas do qual, na maior parte das vezes, ele sabe o que o provocou. Portanto, esta causa guarda uma relação privilegiada, se bem que não exclusiva, com um visto, um ouvido, um tocar, ou seja, com o sensorial.

Além do mais, o estado emotivo faz parte daquilo que se oferece a ver ao olhar do outro: pode-se ignorar o que emociona, percebem-se todavia os sinais da participação somática que comporta este vívido. A emoção modifica o estado 


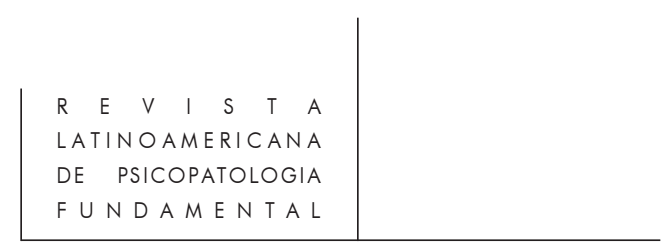

somático e são estes sinais corporais que se oferecem ao olhar, que emocionam aquele que os testemunha e desencadeiam uma mesma modificação no seu próprio soma, mesmo quando disso ele não é a causa direta. A emoção coloca, assim, dois corpos em ressonância e lhes impõe respostas similares. O corpo de um responde ao corpo do outro, mas como a emoção refere-se ao Eu ( Je), pode-se do mesmo modo supor que este último está emocionado pelo que seu corpo lhe dá a conhecer e a partilhar do vívido do corpo do outro.

As outras manifestações somáticas levadas em conta aqui não se referem ao estado de doença, mas ao experimentado de sofrimento que pode acompanhá-lo, sofrimento que informa ao sujeito e ao outro que "alguma coisa" que pode permanecer oculta veio modificar o estado de seu corpo. Bem entendido, o prazer tem uma igual função de mensagem e de auto-informação, a prova do sofrimento não é nem mais nem menos importante do que a do prazer: as duas são necessárias e as duas são incontornáveis. Mas enquanto o sofrimento apela ao poder daquele suposto capaz de modificar a realidade somática e o meio que cerca o "sofredor", o prazer (como mais tarde o gozo) é acompanhado da mensagem inversa: o que poderia modificar-se no corpo ou no exterior é percebido como uma ameaça. Estes sinais e estas mensagens à fonte somática terão um impacto determinante na disposição deste tempo da infância, durante o qual o meio familiar, e mais particularmente a mãe, tem o encargo de zelar pelo estado do corpo e descobrir as manifestações que expressam o estar-bem do corpo, ou, ao contrário, o "mal" presente e, na maior parte das vezes, decodificado como o sinal anunciador do perigo ainda não conhecido que ronda a criança. Nesta perspectiva pode-se dizer que a criança oferece ao olhar da mãe as manifestações do seu bem-estar, mas impõe-lhe as manifestações do seu sofrimento, sobretudo por este último deter um poder de acusar aqueles aos quais ele se mostra (acontece que ele exerce uma igual função de auto-acusação para o sofredor). O sofrimento em geral, mas particularmente o da criança, deixa raramente indiferente o olhar dos outros.

Ele desperta, na maioria, a lembrança da fragilidade, da dependência, da necessidade de ajuda, conjunto de traços que fazem parte da representação que o adulto guarda dentro de si da criança que ele foi. Mais do que qualquer outra vivência infantil, o sofrimento induz um movimento de identificação naquele que não é mais criança e que vai reocupar momentaneamente ou o lugar da "criança sofredora" ou o lugar daquele que poderia abolir todo sofrimento, poder que se imputava a seus próprios pais.

Esta empatia nos explica em parte, pois outros fatores vêm se juntar aí, porque o sofrimento vivido pelo corpo da criança permite-lhe operar este trabalho psíquico, que transformara um acidente, uma prova que fazem parte de uma experiência universal, neste evento singular que tomará lugar nesta história, do mesmo modo singular que ela se constrói do seu corpo e de sua psique. Para isso, na verdade, o 


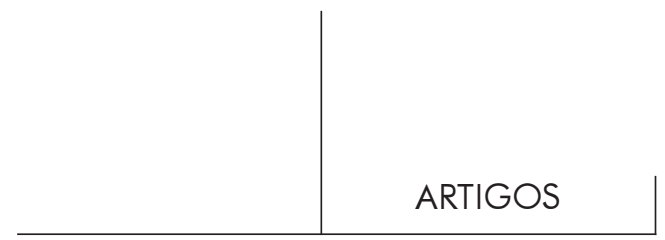

único sofrimento não basta: é preciso acrescentar aí a resposta que ele obteve, seria o silêncio, neste caso carregado de sentido e, antes de tudo, o discurso que a mãe poderá fazer a posteriori sobre o sofrimento experimentado. $\mathrm{O}$ relato que a mãe fará da prova sofrida pelo corpo ou a maneira como ela a excluirá do discurso que faz à criança sobre seu passado terão uma ação determinante sobre a relação que o sujeito manterá com este "mal" do qual poderá padecer seu corpo ao longo da sua existência. A um primeiro sofrimento há muito desaparecido, vai se substituir este discurso que permite ao sujeito guardá-lo na memória: discurso que ressoa aos seus ouvidos cada vez que um sofrimento somático reaparece no seu corpo num conflito relacional que vai marcar sua vida psíquica.

Esta "historização" da vida somática exige a presença de um biógrafo que pode, só ele, religar o acidente a um evento que torne responsável pelo seu próprio destino psíquico. Ainda para isso é preciso que ele possa ocupar o lugar daquele pelo qual e ao qual "eventos acontecem" e não o lugar do evento ele mesmo. Não há biógrafo nem biografia enquanto a uma primeira indissociação espaço psíquico-espaço somático não se seguiu uma colocação em relação destes dois espaços, psique e corpo ocupando cada um dos dois pólos. Esta correlação marca a passagem do corpo sensorial a um corpo relacional que permite à psique atribuir uma função de mensageiro às suas manifestações somáticas e ler nas respostas feitas a este corpo mensagens que lhe seriam endereçadas. O futuro desta relação não só é variável de sujeito para sujeito, mas deve permanecer modificável em cada sujeito, conforme as experiências com as quais o confrontam vida psíquica e vida somática. Vou apenas esboçar estes "destinos relacionais" que ligam o devenir do corpo e o devenir da psique, para me deter sobre o que se organiza por ocasião de um primeiro encontro entre a psique e este corpo sobre o qual se exerce logo a ação do mundo. O percurso que vou seguir parecerá menos obscuro se eu formular logo as três hipóteses sobre as quais ele se apóia:

1. $\mathrm{O}$ ato que inaugura a vida psíquica coloca um estado de mesmidade (mêmeté) entre o que acontece numa zona sensorial e o que dele se manifesta no espaço psíquico.

2. O Eu (Je) não pode nem habitar nem investir um corpo desapossado da história do seu vivido. Uma primeira versão construída e aguardada na psique maternal, acolhe este corpo para unir-se a ele. Faz sempre parte deste "Eu ( Je) antecipado" ao qual se dirige o discurso maternal, a imagem do corpo da criança que se esperava. Se o $\mathrm{Eu}(\mathrm{Je})$ antecipado já é um $\mathrm{Eu}(\mathrm{Je})$ historiado que insere logo a criança num sistema de parentesco e por aí numa ordem temporal e simbólica, a imagem corporal deste Eu $(\mathrm{Je})$, tal que a construiu o porta-voz, guarda a marca do seu desejo (o desejo maternal). Se lhe é proibido sonhar com os olhos abertos que esta criança a vir realizará a volta do seu pai ou da sua mãe, que ela será homem $e$ mulher, que ela estará para sempre ao abrigo da morte, a mãe tem o 


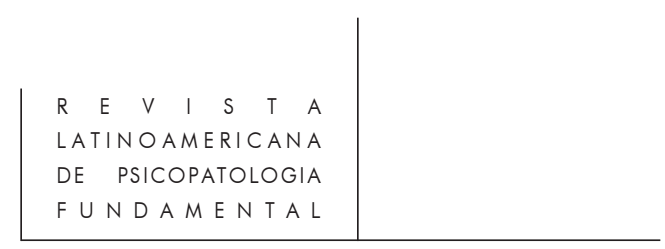

direito (e aí está uma necessidade para a criança) de sonhar com a beleza, com as semelhanças futuras, com a força deste corpo a vir. Falo, claro, de sonho acordado. Mas quando se toma o risco (necessário) de criar-se e de pre-investir uma imagem na ausência de seu suporte real, toma-se também o de descobrir a não conformidade, o desnivelamento entre a imagem e o suporte. Eis aí uma aposta inevitável que geralmente a mãe conseguirá ganhar. Mas pode acontecer de a imagem não poder compor com um corpo diferente demais, estranho demais para o olhar maternal. A mãe encontra sempre o corpo do infans como um risco; ela pode também encontrá-lo como uma resistência ou como desmentido, fonte de um conflito imediato e, às vezes, insuperável. Veremos no fim deste texto porque este conflito pode ser responsável por uma situação de luto completamente peculiar.

3. A partir do momento que a psique pode e deve pensar seu corpo, o outro e o mundo, em termos de relações, começará o processo de identificação que faz com que todo lugar identificatório resulte da dialética relacional entre dois Eu (Je) e que toda mudança num destes dois pólos repercuta sobre o outro. A partir deste momento, o corpo (suas mudanças, sua sexualidade, seus eventuais acidentes) poderá tornar-se o representante do outro e a testemunha de seu poder de modificação sobre a realidade, cada vez que a relação entre o sujeito e este outro se torne demais conflitante e por demais dolorosa.

A relação Eu $(\mathrm{Je})$-corpo substituindo-se à relação Eu $(\mathrm{Je})$-outro retomará para si um mesmo conflito.

Esta substituição pode induzir o outro a importar-se com seu corpo a preocupar-se com o que lhe acontece, a cercá-lo de "cuidados": quando for o caso, o corpo lhe dará de novo seu lugar legítimo e tornará a tomar o papel de mediador relacional que continuará a desempenhar no decorrer da infância. ${ }^{3}$ Se o outro permanece cego ou surdo ao que acontece ao corpo ou se suas respostas são inadequadas, o que era uma substituição provisória pode se tornar um estado definitivo. O corpo, ao ocupar o lugar do outro, preserva para a psique a última possibilidade de guardar o sinal "relação" nos seus "alfabetos", sinal indispensável à organização das construções do primário e do secundário.

Uma substituição transitória entre o outro e o corpo é um fenômeno ao qual todo sujeito recorrerá, ou para fazer apelo a ela para modificar as respostas recebidas, ou para que esta substituição seja imposta pelo próprio corpo. O perigo de morte que o corpo pode efetivamente correr, uma mutilação que arrisca de

3. No decorrer da infância e depois, mas de maneira mais esporádica, se a criança pôde "herdar" de um corpo que conseguiu superar as "doenças infantis" da psique. 


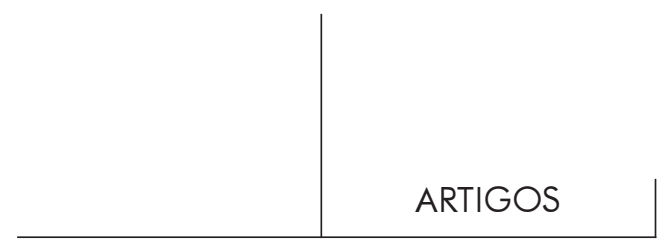

desapossar o Eu (Je) de uma função particularmente investida, vão modificar a relação entre psique e corpo e, no melhor dos casos, fazer ocupar pela psique o lugar de um reparador e de um protetor do corpo, o tempo necessário para que o perigo seja superado ou para que a psique possa mobilizar defesas para elaborar aquilo que ela deve resignar-se a perder, referente à sua própria imagem do corpo.

Quando esta substituição se torna permanente, fica-se confrontado com três quadros.

No primeiro que se depara na psicose, o outro e o corpo tornam-se destinatários intermutáveis. A relação que o sujeito mantém com seu próprio corpo é a retomada daquela que ele mantém com o outro. Esta relação com o corpo que pode, às vezes, tomar a forma negativa, pode também servir-lhe de escudo contra toda tentativa da parte do outro de fazer intrusão no seu mundo psíquico, para recolocar em causa e em canteiro de obras uma relação para sempre imobilizada (congelada). Neste caso, este "encolhimento" (contração) numa relação com o único corpo permite ao sujeito sobreviver apesar desta gelificação relacional nos limites do vivível.

No segundo quadro, o corpo torna-se o mediador e a aposta únicos da relação; é só através do que acontece a seu corpo que o sujeito vai decodificar o desejo do outro em relação a ele e impor o reconhecimento do seu próprio. O sofrimento do corpo, seu mau funcionamento, ocupem então a mesma função relacional que de direito, detém o gozo. O gozo que acompanha o encontro entre dois corpos manifesta a prova do investimento que liga dois Eu ( Je), da concordância total, mas sempre momentânea dos seus fantasmas e dos seus desejos. No caso aqui analisado, o sofrimento suporta e alimenta um conflito não mais momentâneo mas permanente, o que garante, por sua vez, a permanência da relação.

Um terceiro quadro pode apresentar-se, embora menos freqüente: o sujeito recusa toda função relacional a estado de sofrimento e a estado de prazer experimentados pelo seu corpo. Ele guarda a convicção, que clama alto e forte, que nem sofre nem goza por causa ou graças a um outro, mas sim porque seu corpo, todo corpo responde "por natureza" de tal maneira a tal stimulus. A única realidade "natural" é responsável pelo sofrimento, é ela que ele acusa do mesmo modo que ele a acusará de ser totalmente não modificável pelo sujeito.

Encontra-se aqui uma relação com o corpo próprio que se inscreve numa relação mais global com a realidade e que vem lembrar que, paradoxalmente, o lugar primeiro que o Eu ( $\mathrm{Je})$ parece acordar à realidade e aos seus poderes é a consequiência do pouco investimento do qual ela goza, da dificuldade que o sujeito encontra para não desviar-se dela totalmente ou para não se deixar invadir pelo ódio que ele experimenta a seu respeito. Ódio que será sustentado e disfarçado pela constância deste "mal" em obra no seu corpo. 


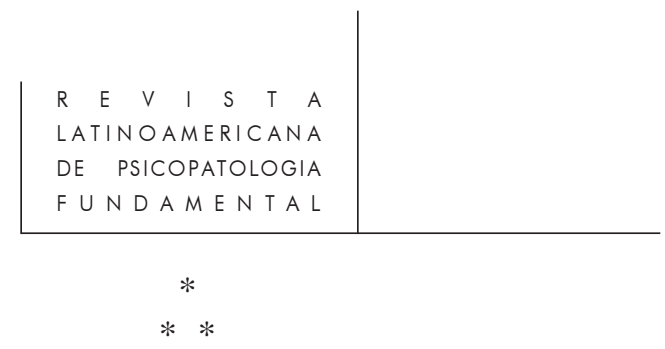

Cada uma destas hipóteses mereceria que se dedicasse a ela um tempo de elaboração mais compatível com a escrita de um livro do que de um ensaio. Escolhi privilegiar a primeira e destacar resumidamente seu impacto sobre as duas outras.

\section{A “colocação em vida” do aparelho psíquico}

Freqüentemente comparei a ação do primário com a de um encenador e a ação do secundário com a de um colocador em sentido, mas ambos têm como pressupostos esta "colocação em vida" do aparelho psíquico, que se deve à atividade dos nossos órgãos dos sentidos. A vida da psique tem como primeira condição a possibilidade de auto-apresentar sua propriedade de organização viva. Os primeiros elementos do único "alfabeto" ou da única paleta que o originário pode usar, são o produto da metabolização a que a psique faz que se sujeitem as também primeiras informações que lhe traz a atividade sensorial pelas suas reações a estes stimuli que acompanham o que se inscreve, desaparece, se modifica, sobre a cena do mundo. Mas estes stimuli que o mundo emite não se transformariam em informações psíquicas se alguém não fizesse o papel de emissor e seletor deste subgrupo de stimuli que, neste primeiro tempo da vida, só podem ser metabolizados pela psique em reveladores dos seus próprios movimentos de investimento e de desinvestimento.

Por elementar ou complexo que seja um organismo vivo, não se pode estudálo isolando-o deste meio ambiente que age sobre ele e ao qual ele reage. Para que a vida somática se preserve, é preciso que o meio ambiente físico possa satisfazer as necessidades incontornáveis do soma. Para que a vida psíquica se preserve, é preciso que o meio ambiente psíquico respeite exigências igualmente incontornáveis e que, ademais, ele aja sobre este espaço de realidade sobre o qual o recém-nascido não tem nenhum poder direto. Na maioria dos casos é a mãe que se encarrega desta dupla função e, conjuntamente, deverá organizar e modificar seu próprio espaço psíquico, de maneira a corresponder às exigências da psique e do infans. Meio ambiente físico e psíquico trarão a marca do modelo que propõe o discurso cultural e mais particularmente o discurso paternal. Marca necessária para relativar aquela a quem se deve os únicos efeitos exercidos por um primeiro meio ambiente sobre a psique da criança, que foi a mãe, e pela lembrança remodelada que esta guarda dela, mas esta última marca permanece, contudo, a mais determinante. Eis por que a mãe será o agente privilegiado das modificações, especificando este meio psíquicofísico que acolhe o recém-nascido: é sob a espécie deste "modificador" que o infans 


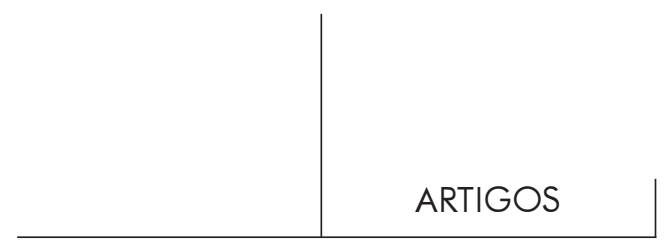

vai encontrá-la ${ }^{4}$. Se ele começa por ignorar sua existência, não pode furtar-se às consequiências destas modificações do seu meio ambiente mais próximo que irão ao par com uma modificação do seu próprio experimentado somático e psíquico. À falta de poder tomar conhecimento de um "modificador" separado, os movimentos afetivos co-extensivos do seu próprio vivido se apresentarão à psique como autoengendrados pelo seu simples poder. Do lado da mãe encontramos, ao contrário, uma psique que já historiou e antecipou o que se representa nestes encontros e que decodifica logo os primeiros sinais de vida através do filtro de sua própria história, escrevendo assim os primeiros parágrafos do que será a história que a criança se contará sobre o infans que foi. Mas, neste momento, deixemos de lado a mãe para voltar a essas produções inaugurais da vida psíquica do infans. Debati longamente sobre este problema no capítulo de $A$ violência da interpretação dedicado aos conceitos de processo originário, pictograma e a este postulado do autoengendramento que decide sobre a organização destes últimos. Permito-me reenviar o leitor a esse capítulo, contentando-me aqui insistir sobre o papel que tem a sonsorialidade para dar vida ao aparelho psíquico. ${ }^{5}$ As pesquisas atuais sobre as interações mais precoces entre aquele que entra num mundo vivo e aqueles que o habitam, convidam a propor esta hipótese: entre os stimuli captados por nossos

4. Dar, como o fazem a maioria dos analistas, um lugar predominante à mãe, não comporta por isso o esquecimento do lugar que ocupa o pai. Desde este princípio de vida, o pai exerce também uma ação modificante sobre o meio ambiente psíquico do recém-nascido. Mas na quase totalidade dos casos, uma pessoa - e mais freqüentemente a mãe - tem um papel nutriente privilegiado. Seja que ela ofereça um seio ou a mamadeira e traz, desta feita - por desejo ou por dever - uma satisfação vital ao infans. Esta pessoa que tem o poder de responder às necessidades e, assim, estar na fonte das primeiras experiências de prazer como de sofrimento, vem ocupar este papel de modificador da realidade somatopsíquica, através do qual se pré-anúncia a presença de um mundo habitado.

Eis por que a mãe é também aquela através da qual o primeiro "sinal" da presença de um pai ou de sua ausência fará brecha na psique do infans: sua escolha destes "sinais" dependerá da sua relação com este pai. Num tempo ulterior, mas sem dúvida muito próximo, a criança poderá recusá-los para forjar os seus próprios e, por aí, instaurar uma relação ao pai de acordo ou desacordo com aquela que a precedeu. Além do mais, no registro do tempo há efetivamente uma primazia da relação com a mãe, da mesma forma que a experiência da gravidez induz na mãe uma forma de investimento para este ser que ela carrega dentro dela, que não é da mesma qualidade que aquela que o pai coloca em lugar durante sua espera da criança.

Eis aí um privilégio "natural" do qual o homem trará sempre a marca positiva ou negativa.

5. Piera Aulagnier. A violência da interpretação, 1975. Todo este texto se apóia e prolonga as hipóteses metapsicológicas defendidas nesse livro, referente ao conceito de processo originário que ele introduziu. 


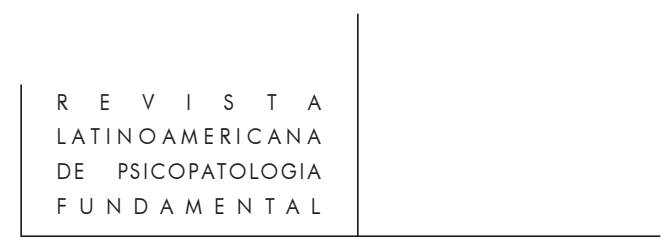

receptadores sensoriais, alguns em função da qualidade e da intensidade da excitação, mas, ainda mais, em função do momento em que se faz o encontro zona-stimulus ${ }^{6}$ darão origem a um experimentado sensorial que tem o poder de irradiar no conjunto das zonas. O prazer ou o sofrimento de uma zona tornam-se prazer ou sofrimento para o conjunto dos sentidos. ${ }^{7}$

Se ficamos neste único processo representativo, observamos que o objeto não existe psiquicamente, a não ser pelo seu único poder de modificar a resposta sensorial (e logo somática) e, por esta via, agir sobre o experimentado psíquico. Donde esta primeira constatação: nas construções do originário, os efeitos do encontro tomam o lugar do encontro. O que explica porque prazer e sofrimento não podem se apresentar à psique a não ser como auto-engendrados pelo seu próprio poder. Mas se estes "efeitos dos sentidos" fornecem à psique estes sinais da existência do mundo que ela pode metabolizar nos únicos que possam afetar, impressionar sua superfície, viu-se também que a maior parte destes stimuli têm como emissor e seletor principal a mãe. Sua qualidade, sua freqüência, dependem do que o "emissor" quer transmitir ou transmite contra sua vontade; logo, ele é parte lucrante no efeito prazer ou no efeito sofrimento que daí resultará. Então a segunda constatação: este prazer ou este sofrimento que a psique apresenta a si como auto-engendrados são o "existente psíquico" que antecipa e pré-anúncia o objeto-mãe. Um experimentado do nosso corpo ocupa o lugar que mais tarde ocupará a mãe: ao Eu (Je) antecipado faz, pois, pendente uma "mãe antecipada" por um experimentado de corpos. ${ }^{8}$

Temos então o ponto de partida desta relação criança-mãe que o sujeito descobrirá e investirá ulteriormente, mas que ele poderá também, por momentos, desinvestir para retornar a uma relação psique-corpo remodelada.

Terceira constatação: Antes que um olhar encontre um outro (ou uma mãe) a psique se encontra e se reflete nos sinais de vida que seu próprio corpo emite.

6. A tomada em conta do "momento" em que se opera a sucessão dos encontros entre a psique e o mundo é um fator cuja importância me parece cada vez maior.

7. Tais experimentados somatopsíquicos de prazer facilitarão a representação futura de um corpo unificado. Ao inverso, a psique, assim que ela tenh os meios, tentará opor-se a este poder "irradiante" do sofrimento com o risco de dispor apenas de uma representação fragmentada do espaço somático.

8. Esta "mãe antecipada" pode ser aproximada do que Bion define como pré-concept: num caso como no outro, um molde relacional espera e precede aquela que será um dos suportes destes. Mas a similitude não vai além disso: a hipótese de Bion faz apelo a uma visão que não deixa de lembrar o conceito kantiano de intuição. A minha, mais "materialista", supõe a presença deste "elemento de realidade" que um vivido somático fornece. 


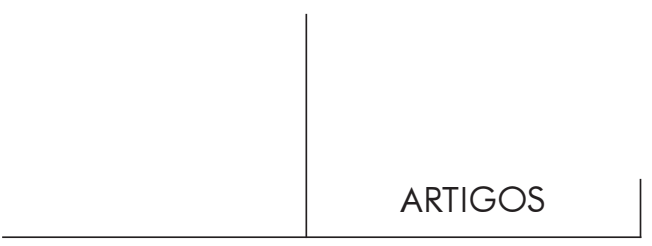

Três constatações que provam que o pictograma do objeto-zona complementar é bem o único do qual dispõe o processo originário. (Seria interessante refletir, numa perspectiva analítica, sobre as reações psíquicas que seguem certas experiências de privações sensoriais).

Este poder dos sentidos de afetar a psique permitir-lhes-á transformar uma zona sensorial numa zona erógena. ${ }^{9} \mathrm{O}$ primeiro ouvido psíquico não capta sons e ainda menos significações, ele capta as variações do seu próprio estado, do seu próprio experimentado, a sucessão de uma experiência de prazer e de uma experiência de sofrimento. E se este prazer ou este sofrimento faltam, a reação sensorial pode existir fisiologicamente, mas ela não terá existência psíquica. No tocante ao originário, quero sublinhar com duplo traço um ponto: pouco importa que o tempo durante o qual este processo é o único a poder transformar os sinais da vida somática em sinais da vida psíquica, tenha uma duração de 3 horas, 3 dias, 3 semanas, sua atividade, nem por isso deixará de persistir ao longo da nossa existência.

Proponho comparar os materiais dos quais se alimentam os processos originários, primário e secundário, a 3 conjuntos de elementos compondo 3 escritas ou 3 línguas, tendo cada uma suas leis sintáxicas próprias. Não faz parte dos elementos da escrita originária este "meta-signo" (o signo relação) que seria necessário para que ela desse lugar nas suas figurações ao conceito do "separável". Por não se achar presente, não se estabelecerá relação entre estas produções e um destinatário suposto aí responder. Suas figurações compartilham o caráter de certos enunciados; elas são performativas, o escritor é o que se escreve, e este "escrito" é conjuntamente figuração de uma exigência e de uma auto-resposta. O que se escreve (ou se pictografa) metabolizou um estado somático na apresentação de um afeto psíquico, conjuntamente experimentado e figurado como auto-engendrado.

A escrita que usará o primário possui este meta-signo (quero dizer o signo "relação") necessário por fantasmar o desejo presente entre o fantasmante e o desejo imputado a este outro, remodelado na sua colocação em cena (mise en scène). É verdade que enquanto só se considera o primário, esta realização fantasmática coloca em cena uma relação de fusão, de posse, de domínio... dois espaços, mas um único desejo todo-poderoso e sempre realizado. ${ }^{10}$

9. Falar de zona erógena é, ipso facto, passar do registro do corpo ao registro psíquico: na terminologia psicanalítica, os tempos prazer e sofrimento, sejam quais forem suas fontes e a atividade que os produziu, só fazem sentido quando aplicados a um experimentado psíquico.

10. É preciso entender a expressão fantasma de fusão: o desejo realizado neste fantasma é a fusão entre dois espaços psíquicos, dois corpos, dois prazeres. O que é negado se refere ao poder de recusar este estado de fusão. Mas isto supõe que sua separação tenha sido percebida e que ela tenha sido abolida, substituindo-a uma relação de fusão, de reunificação entre duas partes que excluiriam a mais ínfima diferença ou que se revelariam complementares. 


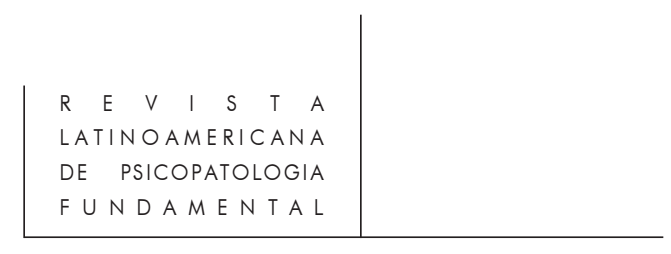

Os signos que a linguagem secundária usará nos seus enunciados têm a particularidade de serem duplamente a serviço das leis que regem uma relação de comunicação recíproca: o enunciado se constrói logo, em referência ao destinatário ao qual se dirige, e os signos desta linguagem são comunicados a este que não os possui ainda, por aquele que já teve acesso a eles. Como em toda língua conhecida, certas palavras desta terceira linguagem psíquica cairão em desuso; outras se tornarão proibidas, novas serão inventadas. A língua que falamos para descrever o mundo é marcada pelo movimento histórico da cultura que a fala; a linguagem que nos serve para tomar conhecimento dos nossos desejos, dos nossos sentimentos, de nossos projetos identificatórios é, antes de tudo, marcada pela história singular de cada enunciante, pelas suas exclusões, seus esquecimentos, suas inovações.

Uma vez estas três línguas aprendidas, a psique continuará a fazer uso delas ao longo da sua existência. Mas enquanto uma parte dos signos do primário e do secundário podem cambiar-se para resultar na colocação em forma de uma espécie de língua composta, a precedência sendo tomada por uns ou por outros, conforme os vividos afetivos do enunciante, não acontece o mesmo com a língua originária. Esta última continua ignorando que corpo e psique reagem e vivem graças a este estado de relação contínua entre eles, e de ambos com seu meio ambiente.

A escrita do originário só pode dar a forma a esta corporeização figurativa que o pictograma propõe, única figuração que a psique pode forjar do seu próprio espaço, dos seus próprios experimentados afetivos, das suas próprias produções.

O processo originário nada conhece do mundo a não ser seus efeitos sobre o soma, do mesmo modo que só conhece desta vida somática as conseqüências de sua ressonância natural e constante com estes movimentos de investimento e de desinvestimento que assinam a vida psíquica. Ignoro se este fundo representativo que continua a tomar emprestado do soma seus materiais, é a causa ou a consequiência da preservação desta participação do corpo aos nossos estados afetivos e emocionais, mas sob o risco de cansar pela insistência, vou tornar a falar sobre uma das consequiências da atividade permanente deste "fundo representativo".

Os efeitos somáticos através dos quais a vida do mundo abre brecha em todo novo organismo, não são um fenômeno transitório; eles não cessam senão com a morte. Freud falava de uma "fonte somática" do afeto: eu sugeriria de bom grado a expressão de uma "fonte somática da representação psíquica do mundo", para sublinhar que tudo o que existe só se torna tal para o processo originário através

Poder-se-ia juntar a este fantasma esta fórmula matemática: 1+1=1, o resultado está errado, mas o signo entre dois termos está preservado. 


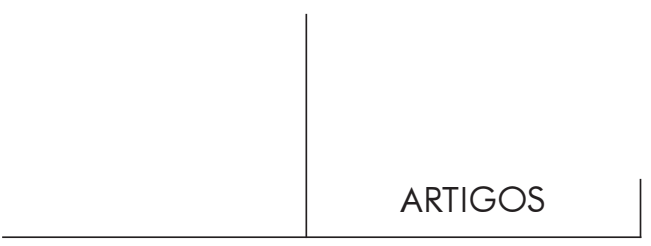

do seu poder de afetar a organização somática (é deste "tudo" que fazem parte, bem entendido, as próprias produções psíquicas). Esta figuração de um mundocorpo que é o pictograma, não pode ter lugar no processo primário ou secundário, nem fazer parte de nenhum recalcado secundário que só contém representações que já sofreram o trabalho do diretor (metteur en scène) e daquele que dará o sentido. Não se deve cair na armadilha da construção teórica que proponho: se ela se aproxima do que eu penso ser o pictograma, ela também confirma que é só do exterior que podemos imaginar este "ser" psíquico, que devemos para isso colocar nossos óculos teóricos e colocar diante de nós, e à distância, o que tentamos ver. Não poderemos nunca, nem pensar, nem fantasmar o interior, o efeito somático como único representante do mundo e a vida psíquica como único reflexo deste efeito do corpo. Mas esta construção teórica permite entender o papel que pode desempenhar novamente o que se organizou neste tempo psíquico que precede este olhar sobre o mundo que o tornará fantasmável e pensável pelo e para o sujeito. Cada vez que a nossa relação com o mundo se furta a toda apreensão dentro de um fantasma ou de um pensamento, à falta de ter podido preservar o investimento, a pelo menos um dos seus ocupantes, encontramo-nos numa situação próxima, se bem que não idêntica, daquela que inaugurou nossa existência: a vida do mundo e o mundo não são mais representáveis a não ser através dos "efeitos somáticos" que acompanham a angústia de um encontro com uma cena vazia.

A representação deste vivido somático será o último recurso, permitindo aos processos primário e secundário fantasmar e pensar sua relação com esta última e única construção psíquica, através da qual traços do mundo continuam a existir para a psique. Preserva-se assim uma última colocação em relação que é a condição mesma para que o primário e o secundário não sejam acuados a cessar sua atividade, o que comportaria ao mesmo tempo o silenciar do aparelho psíquico que, salvo morte precoce, terá sempre, bem ou mal, aprendido a falar suas três línguas e não pode esquecer totalmente uma delas sem se tornar mudo.

O mundo no qual se move o autista e certos fenômenos alucinatórios particulares que encontramos no vivido psicótico, nos esclarecem sobre as conseqüências da catástrofe que representa para o sujeito o desaparecimento do signo "relação" no seu capital representativo ou, mais exatamente, a redução do seu uso a uma forma relacional determinada uma vez por todas, imutável. ${ }^{11}$

Muitos trabalhos analíticos dedicados à criança autista e esquizofrênica parecem confirmar minha concepção do originário.

11. Um desaparecimento total deste sinal não é compatível com a preservação de qualquer vida psíquica, uma vez ultrapassada a aurora da nossa existência. 


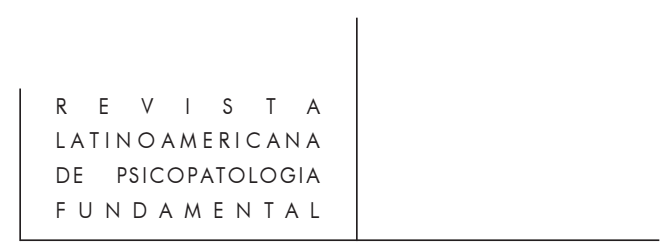

O que nos dão a ver estas pesquisas sobre o estatuto que o autista impõe ao objeto, senão que a criança substitui a este seu único poder sensorial, que está aí a única propriedade que o torna existente para ele?

O objeto não existe mais, e nada resta senão esta sensação de dureza própria a esta pequena coisa de madeira ou de ferro que a mão tritura e manipula de maneira estereotipada, este movimento repetitivo que o faz cair, rodopiar, tornar a pegar pela mão.

E do mesmo modo (eu me refiro mais particularmente aos trabalhos de Frances Tustin sobre o autistic shape) esta marca "suave" que a língua imprime sobre a parede interna da bochecha, este aglomerado de saliva que pode juntar-se a tal ou tal superfície da cavidade oral. Quanto ao corpo no seu conjunto, ele pode, por momentos, não existir mais a não ser pelo e dentro deste movimento rítmico, deste balanço, estar reduzido na sua totalidade a esta para sensação do movimento que o anima. Estas sensações somáticas, tornadas para a psique únicas provas de sua vida e da vida, são efetivamente autocriadas pelo sujeito. O objeto, uma vez reduzido a seu único poder sensorial, é do mesmo modo efetivamente engendrado por esta auto-estimulação, através da qual a psique leva seu objeto complementar a uma zona e a uma função sensoriais que chegam a garantir-lhe que ela se guardou em estado de sobrevivência.

Quanto ao stimuli de fontes exteriores, o autista vai tentar opor-se a seu poder de intrusão, exigindo a não-mudança do meio ambiente. Ele não pode impor ao mundo a imobilidade, o que significaria sua morte, mas pode tentar exigir a repetição idêntica deste mínimo de movimentos inevitáveis, graças a que ele pode não mais vê-los, continuar a acreditar na fixidez do meio ambiente. Todo stimulus imprevisto que vem do outro - e por aí de um espaço do mundo que não é mais perceptível como um reflexo do espaço do corpo - será recebido como uma intrusão que ameaça explodir este último e destruir este continente que, só ele, pode garantir à psique a preservação do seu espaço e, por ali, de um aparelho psíquico que não pode repousar sobre o vazio.

Queria abordar a questão da automutilação no autismo e este estranho poder de ignorar o sofrimento que deveria tê-lo acompanhado. Todavia, isso me levaria longe demais, mas a estranheza deste comportamento me parece, de uma outra maneira, conformar a indissociação presente entre espaço do corpo/espaço do mundo: impõe-se ao corpo o que não se pode impor a um mundo do qual se quer ignorar a existência. A indiferença ao sofrimento vem confirmar a indiferença a um mundo que se pode destruir cada vez que sua movimentação (mouvance) arrisca imporse? Não é num momento qualquer que a criança autista ou esquizofrênica se automutila. Não afirmo que estas observações, mais do que sumárias, esclarecem esta particularidade do comportamento psicótico frente ao sofrimento, mas elas indicam, em primeiro lugar, um caminho. 


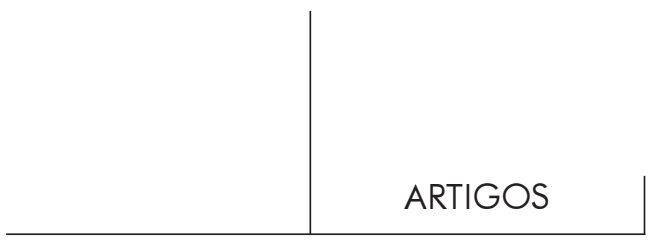

Antes de pôr fim a esta breve incursão no mundo da psicose infantil, vou aproximar estes fenômenos de certas experiências momentâneas presentes no vivido esquizofrênico do sujeito adulto, mas que podem também fazer parte de uma experiência fugidia da qual ninguém está a salvo. A este propósito eu propusera o termo de "alucinações" sensoriais: experiências durante as quais o sujeito não é mais do que esta sensação de um abismo interior onde se afundam os órgãos internos. ${ }^{12}$

Não estou mais tão certa hoje da legitimidade do termo de alucinação. Alucinar é projetar para o exterior o agente de uma estimulação auditiva, visual, táctil, que faz retorno como sinal da hostilidade do mundo, mas do mesmo modo como prova de sua presença e do laço que te liga a ele, laço perseguidor e persecutante, mas laço assim mesmo.

O autista não alucina um stimulus sensorial, ele o cria. Quanto a estas sensações de fonte somática próprias a estas experiências próximas, mas não idênticas, que se encontram fora do mundo do autismo, hesitaria tanto quanto a ver ali uma forma de alucinação no sentido estrito. Eu as consideraria, de bom grado, como a manifestação fugaz do afeto resultando de um encontro entre o sujeito e um evento vivido pela psique como um cataclismo que destruiu momentaneamente toda possibilidade de preservar sua relação ao outro e a seu mundo. Sobra então deste mundo somente e efeito somático deste encontro efetivamente catastrófico: este efeito se torna o representante do mundo, mas esta substituição, como se viu, pode operar somente no processo originário, pode encontrar lugar somente numa representação pictográfica.

Isto significa que entre as possíveis consequiências do encontro entre a psique e o mundo, existe uma que é figurável apenas pelo processo originário. A presença sobre a cena psíquica desta única construção só pode ser uma experiência fugidia, pois os processos primário e secundário deverão conseguir encontrar o mais rápido sua atividade, para dar forma à construções nas quais o signo relação ocupa seu lugar. Desde então o sujeito, num a posteriori imediato, poderá refantasmar e repensar as intenções do mundo em relação a ele mesmo, imputando a elas a causa desta "apresentação" da experiência vivida por seu corpo. Esta formulação $a$ posteriori do que fica fora do dizível no momento mesmo do seu acontecimento, retornará ao nosso ouvido sob a forma daquilo que o sujeito desta vez alucina, projetando para o exterior o agente de uma desorganização do espaço do mundo que se substitui a esta experiência durante a qual foi perturbada a ordem que rege a organização somática e suas respostas.

12. Piera Aulagnier. "A retirada na alucinação: um equivalente da retirada autística?" Conferência proferida no congresso realizado em Mônaco em junho 1984. Publicada no no 3 da revista Lieux de l'enfance. 


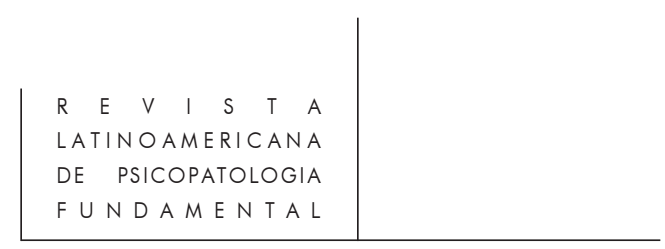

Esta última incursão pelo originário pareceu-me necessária antes de abordar o que vai se passar com o corpo quando do seu encontro com a emoção que suas manifestações causam na mãe, emoção cuja percepção pelo infans inaugura a junção entre sua psique e este discurso e esta história que o esperavam.

Quero lembrar, e primeiro a mim mesma, que este trabalho só tem alguma chance de ser outra coisa do que uma simples reformulação de algo já escrito, graças ao lugar que tento dar aos diferentes estatutos que toma o corpo nas construções sucessivas que a psique se forja delas. Querer elucidar o futuro destas representações, separando-as daquilo que o aparelho psíquico se transformará na sua totalidade, é um artefato, a menos que, como eu sugiro, esta "adição" sobre o corpo possa reencontrar lugar num discurso mais global sobre a psique, da qual ele viria então esclarecer certos pontos cegos. Mas esta história do corpo que eu propus deveria também nos permitir completar aquela que nós nos construímos da psique. Duas histórias que não existiriam se não pudéssemos tomar apoio sobre aquelas que o sujeito se forjou bem antes de nos encontrar.

\section{O corpo da mãe}

Chego à minha segunda hipótese que formularei com uma pergunta: o que representa o corpo do infans para esta mãe suposta esperá-lo a acolhê-lo? Eu diria de bom grado que ali onde a mãe esperava... aquele que teria posto fim a espera? Aquele que provaria a ela a realização do seu desejo de ser mãe? A última elaboração do objeto de um longo sonho começado na sua própria infância? Ela encontra um corpo, eis aí a fonte deste "risco" relacional, ao qual me referi no princípio do trabalho. Este encontro vai exigir uma reorganização da sua própria economia psíquica, que deverá beneficiar este corpo do investimento do qual gozava até então o único representante psíquico que o tinha precedido. Já sublinhei o poder de modificação que a mãe detém sobre esta parte de realidade à qual reagem a psique e o soma do infans, reações que lhe revelam seu próprio poder de ser afetada pela vida do mundo e de ser modificada pelo que a afeta. Mas esta revelação é tanto quanto revelação para a psique maternal: as primeiras manifestações da vida psíquica e somática do infans lhe desvelarão o poder de emoção e de modificação sobre sua própria psique que detém a seu respeito este pequeno pedaço de realidade, quanto próximo, representado pelo corpo de sua criança. As manifestações da vida somática do infans emocionarão a mãe, as manifestações desta emoção modificarão este meio ambiente ao qual reage o infans e, desta feita, os efeitos do mundo sobre sua vida psicossomática. É aqui que se reencontra a importância da componente somática da emoção: a relação da mãe ao corpo do infans comporta logo uma parte de prazer erotizado, permitido e necessário, que ela pode parcialmente ignorar, mas que constitui o embasamento da ancoragem somática deste amor que ela traz ao corpo 


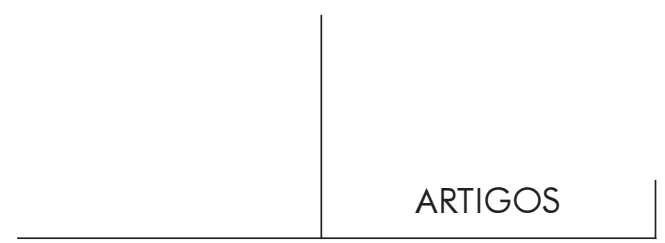

singular de sua criança, amor que, longe de ignorar, ela está prestes a clamar. Este corpo que ela vê, que ela toca, esta boca à qual ela junta seu mamilo, são ou deveriam ser para ela fontes de um prazer ao qual participa seu próprio corpo. Esta componente somática da emoção maternal se transmite de corpo a corpo; o contato com um corpo emocionado toca o teu, uma mão que te toca sem prazer não provoca a mesma sensação daquela que sente o prazer de te tocar.

Se este prazer partilhado entre dois corpos faz parte do lícito, a mãe, todavia, só poderá legitimá-lo ao seu próprio olhar se ela puder religar a emoção experimentada à mensagem de amor, ao pedido de proteção que um $\mathrm{Eu}(\mathrm{Je})$ ainda não acontecido está suposto dirigir-lhe. A primeira representação que a mãe se forja do corpo do infans, logo imputa-lhe um estatuto relacional que vai transformar a expressão da necessidade na formulação de um pedido (de amor, de prazer, de presença) e transformar ao mesmo tempo a maioria dos acidentes somáticos e dos sofrimentos do corpo em um acidente e um sofrimento que tem a ver com a relação que a religa à criança. O que a mãe "vê" das expressões e do devenir de um corpo (seu sono, seu estado de bem-estar ou de sofrimento, seu crescer, seu alimentarse, os primeiros sinais do seu despertar para o mundo, seus gritos e seus silêncios...) vai dar lugar a uma dupla decodificação: por um lado, ela reconhecerá ali os sinais objetivos do estado somático, mas se seu olhar não se torna, para o maior dano para suas relações presentes e futuras, o de uma testemunha neutra, não afetada, estes sinais que tocam sua psique e seu corpo e que serão acompanhados de prazer ou de sofrimento, são decodificados como uma linguagem, antecipando a presença de um $\mathrm{Eu}(\mathrm{Je})$ futuro. O que o olhar maternal vê será do mesmo modo marcado pela sua relação com o pai da criança, por sua própria história infantil, pelas consequiências da sua atividade de recalcamento e de sublimação, pelo estado do seu próprio corpo, conjunto de fatores que organizam sua maneira de viver seu investimento frente a frente com a criança. Eis por que seu olhar acha nas manifestações do funcionamento somático uma espécie de prova através do corpo do infans da verdade dos sentimentos que ela experimenta por aquele que habita este corpo. O vivido deste corpo confirma-lhe alternadamente o bem-fundado da ansiedade que ela experimentou, o bem-fundado da sua culpabilidade por não amálo o bastante, o bem-fundado do sentimento de pecado que acompanhou um nascimento marcado por um interdito, o bem-fundado do poder protetor que ela imputa ao amor que ela traz a esta criança... Esta decodificação, parcialmente arbitrária e sempre singular, vai agir sobre sua reação às manifestações somáticas da criança, decidirá do comportamento maternal, entendendo aqui por comportamento o conjunto de seus atos que vão modificar o meio ambiente do infans. Estas modificações poderão ou não estar de acordo com as motivações inconscientes (um excesso de presença, de contato, tanto pode responder a um fantasma de fusão, como ser uma defesa contra uma agressividade recalcada), e 


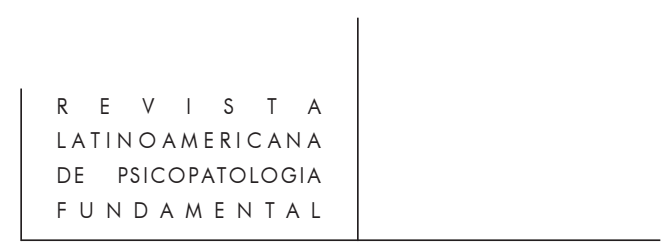

estas motivações agirão sobre a qualidade e a intensidade de participação somática que acompanha o comportamento maternal. A criança perceberá mais ou menos obscuramente o que pode exprimir-se ali de maneira disfarçada, mas isso não impede que o comportamento, seja qual for sua motivação inconsciente, vá agir sobre a disposição objetiva do espaço relacional e tanto quanto sobre o que será dito ou calado no discurso através do qual a mãe torna pensável esta primeira fase relacional e através do qual ela tentará, num tempo ulterior, torná-la pensável ao Eu (Je) infantil. Se o porta-voz (a mãe) acredita "colocar em memória" o que se representa no presente, seu próprio passado, sua própria história logo estão à obra para marcar esta parte do visível, a mais importante, que será objeto de sua interpretação e fonte de emoção. Isso não implica ou não deveria implicar que toda expressão do corpo da criança deva ser interpretada e desencadear um vivido emocional na mãe. Esta última deve permanecer capaz de modificar certos fenômenos surgindo no presente do vivido somático, apelando a este outro discurso sobre o corpo, guardado na "reserva teórica" do seu capital ideativo. Este recurso é necessário para moderar o poder emocional que detém o infans e seu corpo; ele mostra a utilidade desta função de "pára-fantasma" que o "corpo do saber" pode exercer, que torna possível à psique maternal não ver a morte se delinear no horizonte de toda doença, a desnutrição a cada mamadeira recusada. Mas é necessário, do mesmo modo, que este "corpo do saber" não venha ocupar a frente da cena, a não ser o tempo necessário para evitar um excesso, uma somatória de emoções com as quais o infans não poderia compor. Fora estas "pausas emocionais" deverá se preservar uma relação privilegiada (que pode, por momentos, tomar a forma de um afrontamento) entre o corpo psíquico, tal como o forja o processo originário, e este corpo relacional e emocional, obra da psique maternal. Esta relação vai permitir a colocação em cena da representação do corpo que a criança se constrói.

\section{$O$ efeito sofrimento na vida infantil}

Comecemos por nos interrogar sobre o que eu chamaria o efeito-sofrimento na vida infantil. Que a doença tenha ou não uma etiologia orgânica demonstrável, pouco importa à criança que, na maioria das vezes, aliás, não possui este saber sobre a patologia. Mas tivesse conhecimento dela, assim mesmo ela continuaria a se interrogar sobre o que decidiu o encontro entre seu corpo e este vírus (interrogação que, como já foi dito, todo sujeito doente faz, seja qual for sua idade, por pouco que a doença o inquiete), e a criança não imputa nunca este encontro nem ao acaso, nem às fraquezas das suas defesas imunológicas, mas ao que se passa no seu meio ambiente psíquico. Esta "causalidade psíquica" imputada à doença é confirmada à criança pelos efeitos que esta última vai provocar na mãe e pelo discurso que esta vai lhe fazer, tanto sobre sua doença atual como sobre aquelas 


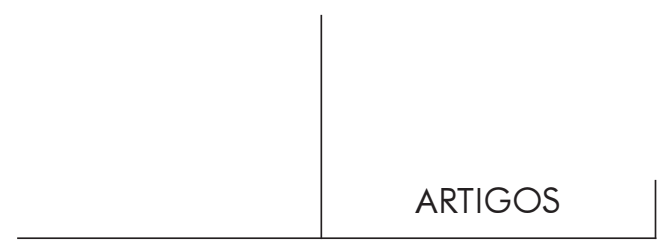

que puderam se apresentar no passado. Em um trabalho sobre o masoquismo, Micheline Enriquez ${ }^{13}$ insistia sobre o papel indutor de um discurso maternal, transformando o sofrimento experimentado pelo pequenino numa espécie de prova que conferiria a este último um estatuto heróico, o tempo do sofrimento sendo magnificado como o tempo que deu nascimento a um herói. Em $O$ aprendiz de historiador, eu insisti, ao contrário, sobre as conseqüências de um discurso que, por seus brancos, desapossa a criança da história passada do corpo do infans que ele foi, história corporal da qual vimos que é indissociável daquela que a psique do infans se forja sobre ela mesma. Se dou um tal privilégio a este sinal de doença que pode ser o sofrimento, é porque, em primeiro lugar, ele tem uma função autoinformante para a criança e, em seguida, porque o sofrimento do corpo da criança vai de uma forma ou de outra induzir uma modificação no comportamento maternal e na organização do meio ambiente. $\mathrm{O}$ sofrimento psíquico pode ser interpretado como um capricho, como a conseqüência de uma frustração, de uma recusa que a criança deve aceitar, como uma manifestação que se pode facilmente modificar e, sobretudo, como um evento, na maior parte das vezes, sem conseqüências para depois $^{14}$ : é por isso que a estes enunciados pelos quais a criança exprime seu sofrimento psíquico (estou infeliz, estou triste, não me amam mais, me abandonaram), a mãe pode opor em sã consciência os seus (você não está infeliz, mas caprichoso, nós não te abandonamos, mas castigamos, não é você que eu não amo mais, mas a criança desobediente que você pode ser). Não se pode dizer o mesmo do sofrimento físico: sua manifestação reveste o caráter da evidência; ela comporta efetivamente um risco que, longe de ser negado, é freqüentemente amplificado; ela nunca deixará a mãe indiferente, seja que ela responda tentando atenuá-la, ou pela fuga do que para ela faz parte do insuportável, ou, ainda, por uma reação agressiva. Então esta primeira consequiência: o sofrimento do corpo induz uma resposta por parte da mãe que retornará até a criança sob a forma de uma revelação sobre o que representa seu sofrimento para o outro. O corpo sofredor, quer a causa deste sofrimento seja um ataque orgânico ou a conseqüência da participação somática a um "ataque" psíquico, terá um papel determinante na história que a criança vai construir do devenir deste corpo e, em seguida, dele mesmo, do que se modifica nele contra sua vontade, do que se gostaria modificar, do que resiste a este objetivo. Assim como já vimos, o inverso acontece na experiência do prazer que se acompanha da esperança que nada se modifique, nem em si mesmo, nem no outro, nem no meio ambiente. Em certo sentido, pode-se dizer que a experiência

13. Micheline Enriquez. "Nas encruzilhadas do ódio", mais especificamente o capítulo 11 (pp. 126 sg.). Paris, Epi, 1985.

14. Convicção às vezes muito errada, mas a qual o casal continua a dar crédito. 
do prazer dá lugar a um único pedido: que nada se modifique. A experiência do sofrimento não apenas "pede" o inverso (que isso se modifique), mas as modificações esperadas variam de um sofredor para o outro e no mesmo. Vão variar também as respostas: pedidos e respostas no registro do sofrimento são polimorfos.

Por esta razão entre outras, propus o termo "somatizante polimorfo" para designar uma componente normal da relação da criança com o outro e com a realidade. Para compreender o porquê deste segundo polimorfismo, não se deve esquecer dois carretáreis especificando o mundo e a vida da pequena criança:

- a ação determinantes que os pais exercem objetivamente sobre o meio ambiente no qual a criança vive, e a impossibilidade para esta última de agir sobre certos dados;

- no que, para ela, fica enigmático e inexplicável nas razões pelas quais a mãe ou os pais justificam o porquê e o como desta disposição de sua realidade; o porquê e o como das exigências que daí resultam para a criança e o lugar que ela deve, desta feita, ocupar.

Não só seu poder de modificação sobre esta realidade é limitado, mas também sua possibilidade de apropriar-se das significações que se referem a ela e que dariam sentido a uma organização que começa por parecer-lhe arbitrária ou caótica.

Ao inverso, ela constata uma simetria no registro emocional entre ela e sua mãe, uma simetria nas suas possibilidades respectivas de modificar sua relação: as modificações serão freqüentemente diferentes, até mesmo antinômicas, estarão, todavia, presentes. Estas modificações do comportamento maternal, pode ser provocada por ela pelas mensagens verbais que ela lhe dirige, obtendo assim satisfação à formulação dos seus pedidos. Mas acontece também que seus pedidos a suas mensagens, expressados pela voz do Eu ( $\mathrm{Je}$ ), revelam-se ineficazes, enquanto a experiência mostrou-lhe que é raramente o caso para aqueles "emitidos" pelo seu próprio estado somático. A criança frente a um meio surdo às expressões do seu sofrimento psíquico, tentará e conseguirá freqüentemente se servir de um sofrimento de fonte somática para obter uma resposta. Resposta, na maioria das vezes, decepcionante: é raro que uma mãe surda ao sofrimento psíquico saiba ouvir o que a criança pede via seu corpo. (Acontece que este sofrimento se torna a única via-voz, desvelando ao sofredor a causa ignorada do seu sofrimento psíquico).

"Servir-se do seu sofrimento somático": com efeito, mesmo se a causa deste sofrimento for puramente orgânica e não deve nada à ação da psique sobre o soma, a resposta que ela provoca não deixará de desvelar à criança o "uso" que ela pode fazer disso. Este desvelamento mobilizará um interesse privilegiado para todo sinal de sofrimento: o que explica a maneira tão diferente como o sujeito vai tratar seu sofrimento, a menos, bem entendido, que ele ultrapasse certos limites. A criança pode sofrer de uma angina e continuar a brincar tranqüilamente, a tagarelar, a 


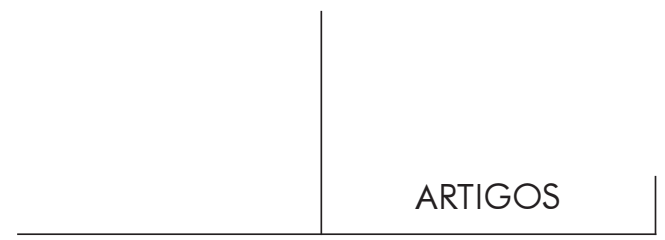

comunicar; ela pode também fazer do seu "mal" na garganta a única via possível de comunicação - não ser mais, a não ser este "mal" - enquanto a resposta, que ela o faça ou não desaparecer, não vem prestar voz ao Eu ( $\mathrm{Je}$ ) "sofredor”, induzilo a reocupar o lugar de um pedinte de cuidados psíquicos.

Passada a infância, e se deixamos de lado o papel do corpo na experiência do gozo, o sujeito apelará tanto menos para seu corpo como transmissor privilegiado de mensagens, quanto terá podido diversificar os destinatários e os objetos do seu pedido. Mas para que esta dupla diversificação dê resultado, ainda será preciso que o corpo ao qual a mãe lhe passará o controle (prise en charge) no fim da infância, tenha como referente um "corpo psíquico" cuja história prove o amor que se dedicou a ele, o reconhecimento e a valorização da sua identidade sexual, da sua singularidade, o desejo de vê-lo se preservar, se modificar, se tornar autônomo.

No caso contrário, as "doenças" das quais continuará a sofrer o "corpo psíquico" farão que o Eu ( $\mathrm{Je}$ ) mantenha com o seu corpo uma relação que retoma aquela que a mãe teve em relação ao corpo da criança ou, mais exatamente, aquela que a criança lhe imputou na história que ela construiu dela. Quando for este o caso, a relação do sujeito adulto ao sofrimento do seu corpo transforma este sofrimento no representante do corpo do infans e da criança que ele foi, infans e criança que tanto se pode desejar reparar, superproteger, ou, ao contrário, odiar, punir com um sofrimento que vai impor-se a ele, ou exacerbar, ou, ainda, simplesmente ignorar, retomando assim em sua conta a surdez maternal.

O corpo sofredor pode sempre reocupar o lugar que o biógrafo tinha dado em um longínquo passado a outros acidentes somáticos, nesta história que os tinha transformado em eventos psíquicos. E como é o mesmo biógrafo que vive o sofrimento presente, a significação atribuída aos sofrimentos passados será parte lucrante daquela que ele atribui ao sofrimento presente, as respostas que se davam a ele como aquelas que ele se dava vão influenciar no que ele irá pedir, quando do retorno do sofrimento, aos outros, a seu corpo, e ele mesmo.

Terminarei este trabalho propondo nos debruçar sobre uma situação e um encontro que vão decidir sobre um tipo de prólogo nesta peça, cujo herói é o corpo e o autor a psique: prólogo tão particular quanto perigoso para a boa composição dos atos que vão seguir.

De diferentes lados, e desde um certo número de anos, um núcleo depressivo presente na mãe quando dos seus primeiros contatos com a criança, veio ocupar um lugar crescente para notificar os mais precoces sinais, os mais imediatos de uma angústia psíquica no infans. Todavia, qualquer que seja a causa desencadeando uma experiência depressiva, ele sempre se manifestará pela impossibilidade do "deprimido" experimentar prazer nos e através dos seus contatos, seus investimentos, impossibilidade de experimentá-lo e logo a mostrar e partilhar com ele seus 


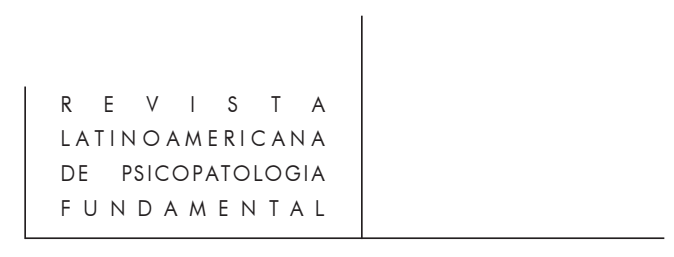

sinais. Deixo de lado a questão tão importante colocada por esta tão precoce capacidade do infans de perceber a vantagem de um prazer compartilhado ou sua ausência, ainda que o que eu disse acima sobre a emoção nos ofereça talvez uma via de acesso. Vamos reter, neste momento, esta ligação entre a depressão maternal, sua impossibilidade de experimentar - manifestar prazer nos seus contatos com a criança, a falta de partilha de um prazer erógeno e as conseqüências destrutivas para a psique do infans, que deve se auto-apresentar como poder de engendrar seu prazer. ${ }^{15}$ Se esta depressão maternal parece quase uma constante entre os fatores "traumáticos", é evidente que ela pode ser a consequiência de um luto, de uma doença, de um conflito agudo... Mas seus efeitos sobre a psique do infans me parecem, numa primeira fase da vida, responder às manifestações da depressão mais do que à sua causa, mesmo se o impacto desta última se reencontra na maneira como a mãe viverá sua relação com a criança, sobre a qual ela projetará logo a imagem daquela (freqüentemente uma primeira criança) da qual ela não conseguiu superar a perda, a sombra ameaçadora de uma imagem do parceiro virando um adversário no conflito que se vive, a sombra de um pai ou de uma mãe desaparecidos, a imagem enlutada do próprio corpo que se acreditava a salvo da doença... ${ }^{16}$

O quadro clínico sobre o qual vou me deter, especifica-se pelo evento responsável da depressão maternal e pelas conseqüências imediatas que resultarão dali para este estado de complementaridade que, durante um tempo, deve religar espaço psíquico e espaço somático, experimentado afetivo e experimentado sensorial. Lembro o que disse acima sobre esta história e esta imagem de um corpo que precedem a chegada neste mundo deste corpo. Vimos que mesmo na hipótese mais otimista de uma futura mãe na qual os mecanismos de recalque, de sublimação, de assunção da castração teriam assumido suas funções estruturantes, este "Eu $(\mathrm{Je})$

15. É evidente que a impossibilidade de experimentar prazer para amamentar, lavar, tocar, seu lactante vai infletir os movimento necessários para assim fazer, mas eu não acredito que se possa estar satisfeito para esta explicação "mecanista" ou "realista" . Eu penso que o experimentado na mãe de um prazer psíquico com seus componentes erotizados é necessária para que o infans possa sentir plenamente suas próprias experiências de prazer. A mãe pode ter o mesmo comportamento gestual, o mesmo tacto, eu sinto que à falta dela mesma experimentar prazer, a falta de uma circulação pela via do corpo de uma experiência de prazer que ela precisa, sob uma forma apta a sua assimilação ou a sua metabolização. Prazer será presente, eis aí uma energia vital sem a qual o aparelho psíquico não poderia funcionar, mas suas qualidades, suas propriedades se traduzirão por anomalias, e antes de mais nada, pela resistência que esta forma de energia oferece para se colocar a serviço das funções relacionais do aparelho.

16. Nós veremos que num caso as conseqüências da depressão maternal sobe o infans são, ao inverso, diretamente religados ao encontro. 


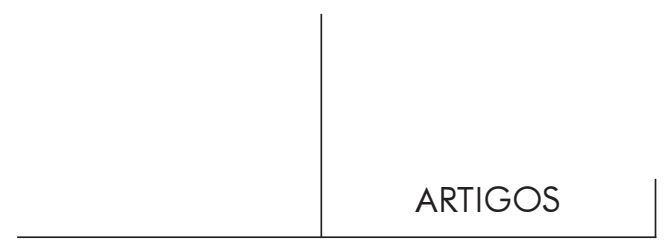

antecipado" traz consigo a imagem desta criança que ainda não está ali, imagem fiel às ilusões narcísicas da mãe e imagem mais chegada de uma criança ideal. (Este pré-investimento explica também porque em toda mãe este infans a nascer será o suporte de tudo aquilo que pode, por momentos, cristalizar sua angústia, sua culpabilidade, seu receio de perda). A experiência clínica nos dá a prova do quão frágil pode se revelar todo aparente equilíbrio psíquico frente a certas provas: sublinhei freqüentemente tudo o que a experiência da gravidez comporta de único e porque, para certas mulheres, ela pode representar uma prova psiquicamente perigosa, pelo fato de que ela vai reativar e remobilizar todo um passado relacional mais ou menos ultrapassado, que elas deverão reviver sob forma inversa. Vimos também que as mensagens, as ofertas que a mãe dirige ao "Eu (Je) antecipado", como as respostas que este último está suposto reenviar-lhe, vão tomar apoio sobre este revezamento representado pelo corpo do infans, suas expressões, seu estado, seus movimentos, sua apatia, seu choro... Ora, este corpo ou, para melhor dizendo, as manifestações que nele exprimem a vida, e a singularidade e portanto esta parte de imprevisto que faz dele um corpo vivo, deverá ser acolhido pela mãe como o referente sobre a cena da realidade deste representante psíquico que o precedeu e o esperou. O corpo do infans é o complemento necessário para estabelecer um estado de junção entre um representante psíquico pré-forjado pela psique maternal e que se referiu à "idéia criança" (ou à sua criança ideal) e esta criança que está ali. O corpo do infans pode, só ele, fornecer à mãe estes "materiais sinalíticos" que asseguram ao "Eu ( $\mathrm{Je}$ ) antecipado" um ponto de ancoragem dentro da realidade de um ser singular que obrigam a mãe e tornam possível a ela preservar seu investimento a seu representante psíquico do infans e, portanto, a este "corpo psíquico" presente na sua própria psique, mas investindo também, ao mesmo tempo o afastamento, porque sinal de vida entre este representante e o infans real. Afastamento que diferencia, mas também religa, e pode religar sozinho, seu corpo psíquico a este corpo singular. Mas o que acontece se esta ancoragem do representante psíquico dentro da realidade do corpo do infans falha? Duas eventualidades são possíveis:

Na primeira confronta-se com um fenômeno de idealização parcial e, desta feita, muito particular: quanto mais o desenvolvimento do infans sublinha este afastamento, mais seu representante psíquico será idealizado, e mais tudo aquilo que é do registro do diferente, do imprevisto, deverá ser negado na criança. A “decodificação" pela mãe das mensagens que o infans emite se mostrará correta quando a mensagem vier confirmar sua própria representação do infans, ela (a decodificação), no caso contrário, inverterá a significação da mensagem. Certos traços do comportamento das funções somáticas, das primeiras manifestações do despertar, da atenção, serão idealizados, superinvestidos; ao mesmo tempo serão desvalorizados, combatidos ou, mais radicalmente, não vistos, todo sinal de vida, 


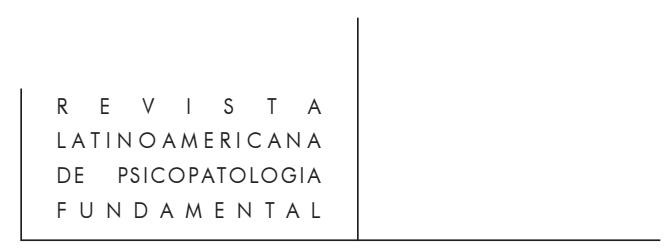

toda modificação que mostram e destacam a diferença. Esta idealização fragmentária arrisca provocar no infans uma insegurança fundamental tocante aos próprios testemunhos sensoriais, uma incerteza mutilante tocante a conformidade entre si próprio e a imagem dele reenviada pelo espelho, uma relação ao ideal bastante estranha. Reações que se encontram no esquizofrênico e que nos esclarecem sobre a função de defesa que pode então exercer o apelo à certeza delirante.

Na segunda depara-se com a impossibilidade para a mãe, frente a esta mesma situação, de operar esta idealização fragmentária que preserva pelo menos certos pontos de ancoragem entre o infans e seu representante psíquico. Impossibilidade que vai confrontá-la a um infans vivo. "Cobrir-se de luto por um vivo": num certo sentido, eis aí uma experiência que nos toca a todos muito de perto porque a vida a impõe a nós quando da rejeição do nosso amor por um outro ainda investido.

Entretanto, uma diferença radical separa estas duas situações: na segunda um sujeito foi primeiro fortemente investido porque pareceu particularmente conforme ao seu representante psíquico. Esta ligação existiu realmente, ela foi até mesmo superinvestida. É por isso que a ruptura que está sendo imposta vai modificar o referente psíquico que se tenha forjado do amado, e permitir pouco a pouco a elaboração de um trabalho de desapego relacionado ao amado e a seu representante psíquico.

Na primeira deve ser instalado o estado de luto, até mesmo de qualquer possibilitado de ligação entre o infans e o representante psíquico que o precedeu e, ainda mais, no momento em que um corpo real não pode permanecer vivo sem uma ajuda exterior que pressupõe um investimento da vida deste corpo. Mas como se poderia investir um "objeto humano", seja qual for, que não tivesse representante psíquico? Como se poderia investir um "vivo" que exige ipso-facto a condenação à morte para seu representante em sua própria psique? Dilema que poderia ser formulado nos seguintes termos: ou a morte do lactante permite a preservação de um representante psíquico, cuja idealização não encontrará nenhum obstáculo e que permanecerá imutável na espera de um novo corpo, ou a vida do lactante se preserva e seu representante psíquico será condenado à morte, mas, neste caso, uma primeira representação relacional mãe-infans deverá ser apagada para sempre da psique para dar lugar a uma nova. Mas qual delas?

A menos que a morte real se intrometa, a mãe fica acuada a uma situação que frisa o impossível. Por um lado, ela deverá preservar um desejo de vida para este infans, investir as funções necessárias para isso, tentar captar as mensagens desorientadas que o corpo do infans emite, e, por outro lado, fazer o luto deste Eu (Je) antecipado que the serviu de decodificador. Para isso ela terá de colocar no lugar um novo referente psíquico, à falta do qual o infans arrisca se tornar um não-existente logo que sua presença não for mais confirmada por um olhar que vê um corpo, que ouve um grito, que constata que uma boca engole um alimento. 


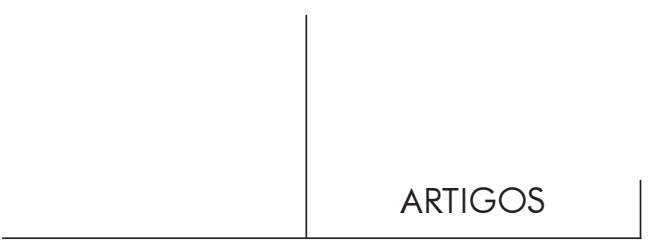

Mas a este novo representante faltará este enraizamento dentro do tempo, de um desejo, de uma história, presente em todos os outros casos. Todo novo objeto investido ao longo de nossa existência vem ocupar o lugar de um já esperado. Ele não é só isso, claro, mas goza daquilo que eu chamei "um investimento em busca de suporte". A experiência nos ensina que não pode servir qualquer suporte, que uma certa "idéia" o precedeu e o antecipou e que é mesmo a descoberta, sempre parcialmente ilusória, da sua conformidade com esta representação antecipada do objeto de espera que desencadeia este fenômeno que se chama amor.

No encontro analisado aqui será preciso ou precisaria que a mãe desse lugar a um representante psíquico do infans, que exige o desaparecimento daquele que o precedeu e que pôde, sozinho, sustentar uma representação relacional mãe/criança conforme à economia psíquica maternal, sem contar que este abandono se impõe numa situação de emergência. Contudo, o que é válido para todo acidente corporal, também o é para todo acidente psíquico: se você sofre uma queda perigosa, alguns segundos são o suficiente para fraturar o seu corpo; no melhor dos casos, meses serão necessários para que os pedaços se ressoldem, e muitos outros meses freqüentemente para achar mecanismos que compensem o handicap funcional que dali poderá resultar. Pois a psique deste tipo de mães sofre o que eu chamaria, de bom grado, um "traumatismo do encontro". Este recém-nascido que se impõe ao seu olhar, situa-se muito malgrado "fora história" ou fora da sua história, ele rompe a continuidade da sua história com o risco de colocar em perigo a totalidade de uma construção, cuja fragilidade tinha ficado escondida do historiador. Fazendo apelo aos meios do seu "bordo psíquico", a mãe deverá tentar restar os fios desta história, religar este tempo presente a um tempo passado, de maneira a poder preservar uma relação com a temporalidade, compatível com o processo identificatório e seu movimento. Se ela fracassa, sua reação depressiva poderá desembocar sobre um estado melancólico, um episódio psicótico ou a instalação de um estado depressivo. No caso contrário, e sejam quais forem os mecanismos psíquicos que lhe terão permitido superar as consequiências deste "encontro traumático", ela deverá conduzir de modo satisfatório um trabalho ainda mais árduo do que aquele do luto e que exigirá, igualmente, um tempo de elaboração cuja duração será variável, mas sempre consequiente. Este tempo vai geralmente coincidir com aquele que será necessário para que o infans passe ao estado de criança, passagem que ajudará a psique maternal a superar seu "trauma", propondo a seu investimento sinais verbais desta vez., que provam a ele a presença de um $\mathrm{Eu}(\mathrm{J} e)$ e a função de mensageiro que este vai fazer exercer a suas próprias construções. Novas construções e novas mensagens que se prestarão mais facilmente à interpretação que a mãe se dá delas para aproximarse daquelas que ela espera.

Mas esta criança foi, em primeiro lugar, um infans mutilado do representante psíquico que deveria tê-lo acolhido. Ela também (a criança) apelará a seus recursos 


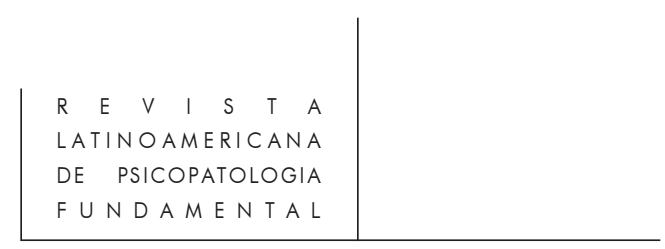

psíquicos para superar as conseqüências desta experiência de desapropriação, deste primeiro tempo que a colocou fora história, e ela também poderá conseguir construir uma história (a sua), mesmo deixando em branco um primeiro capítulo.

O êxito, todavia, se revelará ainda mais problemático para a criança do que para a mãe: de fato, o trabalho psíquico que ele implica incumbe a um Eu (Je) que está no princípio absoluto do seu aprendizado de historiador e de construtor.

Eis por que as consequiências de um tal princípio de vida deixarão, na maioria das vezes, traços indeléveis no funcionamento psíquico da criança ou do adulto que o analista, dado o caso, encontrará. Traços que nos clareiam sobre a particularidade e a complexidade das respostas que a criança soube encontrar para que a vida do infans tenha um seguimento.

O conjunto destas respostas pode ser esperado em três situações que nos fazem captar o mecanismo psíquico determinante em cada um dos três:

a. A psique do infans pode conseguir antecipar a possibilidade da separação, da realidade, de um esboço de compreensão do discurso maternal. Graças a isso, ela facilitará ao máximo a tarefa do decodificador exterior, tornando suas mensagens mais conformes quanto possíveis às únicas respostas que a mãe é capaz de dar. Este "cedo demais" da prova da realidade vai se fazer à custa da autonomia psíquica: logo que ela puder formular pedidos, a criança ficará o mais perto daqueles que ela supõe esperados pela mãe para aproximar-se, assim, deste representante psíquico que ela tinha pré-investido. O biógrafo se transformará em um copiador, condenado a transcrever fielmente uma história escrita por um outro uma vez por todas.

b. Esta antecipação pode não se fazer ou, de qualquer forma, falhar: este outro que a psique encontra não poderá ser investido como portador de um desejo de vida e como dispensador de prazer. $\mathrm{O}$ afeto prazer não terá mais como suporte representativo um fantasma de fusão, mas acompanhará uma atividade autosensorial, cuja figuração psíquica retoma para si o postulado de autoengendramento. Enquanto na atividade auto-erótica o prazer é sustentado pelo fantasma de uma relação fusional com o objeto do desejo, na atividade autosensorial o prazer acompanha, como vimos, uma figuração dentro da qual os efeitos do encontro se tornam os substitutos de um "objeto", cujo referente psíquico reenvia ao único corpo próprio. Se numa primeiríssima fase da vida o postulado do auto-engendramento é o único organizador das construções psíquicas, é mesmo porque a psique maternal organiza um espaço relacional que antecipa a presença de um representante do objeto exterior, o tempo necessário para que a psique do infans possa dar-lhe lugar e apropriar-se por aí este metasigno do alfabeto do primário que abre-lhe o acesso a um espaço e a um mundo relacionais. Ainda será preciso que este acesso, uma vez tomado, não se torne por momentos impraticável: quando for este o caso, o último recurso que a psique 


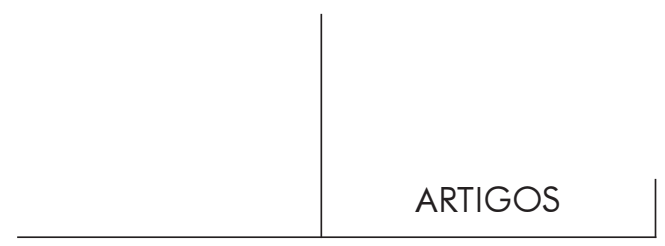

terá, nos confrontará com o mecanismo analisado acima a respeito do autismo.

c. No terceiro caso, constataremos a utilização de uma forma de clivagem inteiramente particular que, embora fonte de conflito, permitirá ao sujeito se preservar tão bem que mal, e antes mal, um espaço relacional. $\mathrm{O}$ objeto exterior reconhecido como podendo só ele satisfazer a necessidade, será desconectado de toda fonte erógena de uma experiência de prazer que se tornou autônoma da experiência e do tempo da satisfação. As conseqüências de uma clivagem tão particular quanto precoce vão ser encontradas no estatuto e na função que preservará o objeto da necessidade. Elas nos esclarecem sobre certas formas de anorexia e de adicção e também sobre a problemática relacional que subentende uma parte destes quadros clínicos que, por não poder classificá-los com precisão, definimos como estados-limite. A relação que a psique estabelece com o outro vai instrumentar-se sobre o único desejo e poder que ela lhe atribui (aqueles de conceder-lhe ou de recusar-lhe o que o corpo necessita), e sobre seu próprio poder de exigir ou de recusar este elemento de vantagem (apport), independentemente do estado real do corpo, quer se trate da alimentação, do sono ou da satisfação de qualquer outra necessidade. Os únicos sinais pelos quais a psique pode dar lugar a um corpo que serviria de revezamento (relais) relacional, são aqueles através dos quais se manifesta um corpo em estado de carência, o que não é o equivalente de um corpo sofredor. Se nós nos colocamos dentro da relação pais/criança, é preciso se lembrar que se a criança não tem o poder de satisfazer, sem elemento de vantagem trazido do exterior, certa necessidades do corpo, está em seu poder recusar este elemento e desencadear, assim, um conflito agudo. Quer se trate da criança ou do adulto, esta recusa, assim como o conflito que ela provoca, se tornarão para a psique a prova do poder que ela detém sobre seu corpo como do laço que continuo a religá-la ao outro: aqui o conflito relacional comporta sempre apostas (enjeux) reais e vitais e, ainda mais, apostas fixadas uma vez por todas. Não haverá mais acidente corporal que possa transformar-se num evento psíquico encontrando lugar neste movimento que especifica toda história. O próprio da necessidade é sua repetição que só pode dar lugar à mesma repetição da interpretação que a psique se dá dela e que ela retoma indefinidamente. Compreende-se, desde então, a imutabilidade da relação conflitante que, a este preço, pode conservar-se entre o sujeito e um outro, evitar ao primeiro, criança ou adulto, encontrar um mundo desértico que ele poderá, no melhor dos casos, povoar com suas miragens.

Minha conclusão se fará com algumas palavras: não há corpo sem sombra, como não há corpo psíquico sem esta história que é a sombra falada dele. Sombra protetora ou ameaçadora, benéfica ou maléfica, que protege com uma luz por demais crua ou que anuncia a tempestade, mas em todos os casos sombra indispensável, pois sua perda implicaria na da vida sob todas as suas formas. 


\section{Resumos}

En partant de la présupposition de que tout l'histoire signifiante se construit à partir de la naissance d'un corps - corps lequel devrait être investie d'une manière libidineuse - l'auteur discute les mouvements constitutifs de la psyché et sa relation avec le corps. L'accent est mis sur le postulat du l'auto-engendrement, qui dit que, si l'espace psychique et le somatique sont inséparables, la psyché imputera à l'activité des zones sensorielles le pouvoir d'engendrer ses expériences.

L'auteur part de ce que le corps rend visible dans les registres de l'émotion et de la souffrance somatique pour compreendre son rôle dans la construction $d u$ "corps latent", qui est son double psychique.

"L'acquisition" du corps par le Je est poursuit graduellement dans le texte. "L'historization" de la vie somatique ne peut pas être fait que par un certain biographe: le Je. Ce Je doit, néanmoins, être capable de reconnaître comment ses événements ont marqué significativement sa vie. Pour que le biographe et la biographie peuvent exister, c'est nécessaire que psyché et corps viennent à se rapporter comme des pôles séparés, en marquant ainsi le passage sensoriel au corps relationnel. Le Je ne peut pas occuper un corps que si celui-ci posséder une histoire. La première version de cette histoire est élaborée par la psyché qui accueilli ce corps. Dans cette histoire sera contenu un "Je anticipé", référent à l'image du corps de l'enfant que la mère anticipe, permettant ainsi que l'enfant soit inséré dans un système parental. Cependant, la situation peut se compliquer quand l'image crée par la mère ne correspond pas au corps avec lequel l'enfant vient au monde. Les conflits insupportables et les deuils irréalisables gérés par cette situation sont débattus d'une manière ample et longue: la psychose, l'autisme, les manifestations psychosomatiques, les somatisations polymorphes.

À la fin du texte il y a une analyse détaillée des conséquences de la non-ancrage $d u$ représentant psychique que la mère apporte du corps d'enfant dans la realité du corps avec lequel l'enfant naît.

Mots clés: Psychanalyse, corp, histoire, investiment.

Assuming that every significant history is built from the birth of a body - which might have been libidinously invested - the author discusses the constituent movements of the psyque and its relation to the body. Emphasis is given to the postulate of selfgeneration which says that while the psychical and the somatic spaces are undissociable, psyque will impute to the activity of the sensorial zones the power of generating its own experiences.

The author starts from what the body lets visible in the registers of emotion and in the somatic suffering, in order to understand its role in the construction of the " latent body", that is its psychical double.

The "acquisition" of the body by the "I" (Je) is followed step by step in the text. The "historization" of the somatic life can only be made by a biographer: the "I". 


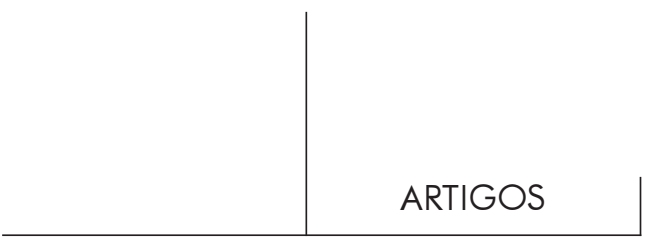

However, this "I" (Je) must be able to recognize its own and particular events which marked significantly its life. It is necessary that psyque and body start to relate to each other as separate poles, in order to permit the existence of both the biographer and the biography. Being so, the passage from the sensorial to the relational body is marked. The "I" (Je) may only occupy a body that has got a history. The first version of this history is elaborated by the psyque that takes in this body. This history will contain "an antecipated I" (Je), which refers to the image of the child's body antecipated by the mother. This permits the child to be inserted into a system of parenthood. Even so, the situation may complicate when an image created by the mother doesn't correspond to the body with which the child comes to life. As a consequence of this situation, the unbearable conflicts and the mournings that become impossible to be made, are exhaustively discussed: the psychosis, the autism, the psychosomatic manifestations, the polimorfal somatizations.

In the end of the text, the author analyses the consequences of the non-anchorage of the psychical representative that the mother brings of the infans's body to the reality of the body with which the child is born.

Key words: Psycho-analysis, body, hystory, cathexis 